\title{
Neprijatelj pred vratima? Ili kako studenti prava iz četiriju najvećih hrvatskih gradova doživljavaju azilante i migrante s Bliskog istoka
}

\author{
Marko Mrakovčić \\ Sveučilište u Rijeci, Pravni fakultet, Hrvatska \\ e-mail:mmrakovcic@pravri.hr
}

\author{
Margareta Gregurović \\ Institut za migracije i narodnosti, Zagreb, Hrvatska \\ e-mail: margareta.gregurovic@imin.hr
}

SAŽETAK U radu se analiziraju stavovi studenata pravnih fakulteta o migrantima s Bliskog istoka i azilantima u Republici Hrvatskoj. Podaci su prikupljeni metodom ankete sredinom 2019. godine na pravnim fakultetima u Zagrebu, Rijeci, Splitu i Osijeku ( $\mathrm{N}=667)$. Konceptualni okvir za objašnjenje tih stavova primarno nalazimo u teorijama konfliktnog pristupa, tj. teoriji grupne prijetnje i teoriji integrirane prijetnje. U tom kontekstu analizira se kako studenti prava doživljavaju migrante s Bliskog istoka i azilante u Hrvatskoj te smatraju li ih stvarnom ili simboličnom prijetnjom za Hrvatsku i zemlje EU-a. U radu se također ispituju razlike u stavovima među studentima različitih sociodemografskih i sociokulturnih karakteristika. Rezultati su pokazali da su politička orijentacija, stupanj (ne)religioznosti i gradovi iz kojih ispitanici dolaze značajno povezani sa stavovima studenta prema migrantima i azilantima. Također se pokazalo da postoji značajna povezanost između stavova prema azilantima u RH i općenitih stavova koje ispitanici imaju prema migrantima s Bliskog istoka, pri čemu najsnažniji, pozitivni učinak na stavove o migrantima imaju spremnost na bliskost i kulturna otvorenost prema azilantima te izostanak percepcije azilanata kao potencijalne ili stvarne prijetnje za društvo u koje dolaze.

Ključne riječi: migranti, azilanti, percepcija prijetnje, stavovi, studenti prava.

Copyright (C) 2020 Institut za društvena istraživanja u Zagrebu - Institute for Social Research in Zagreb Sva prava pridržana - All rights reserved 


\section{Uvod}

Iskustvo Hrvatske kao tranzitne zemlje na tzv. migrantskoj „Balkanskoj ruti“ na prijelazu između 2015. i 2016. godine ostavilo je traga na doživljaju njenih stanovnika o mogućim i stvarnim novim doseljenicima, uključujući i prisilne migrante. U navedenom je razdoblju kroz Hrvatsku prošlo preko 650.000 prisilnih migranata, od čega je tek nekoliko stotina zatražilo azil i ostvarilo status tražitelja azila. ${ }^{1}$ Od rata koji je pratio raspad Jugoslavije to je prvi susret $s$ većim brojem prisilnih migranata u potrazi za zaštitom, tj. izbjeglica. Pritom je važno naglasiti da se karakteristike (n)ovih izbjeglica razlikuju od slike koju mnogi stanovnici Hrvatske imaju pred očima na spomen izbjeglica: ratom raseljene i izbjegle osobe iz drugih dijelova Hrvatske te izbjeglice iz Bosne i Hercegovine, koje su u kulturnom aspektu vrlo slične domicilnom stanovništvu.

Prema Zakonu o međunarodnoj i privremenoj zaštiti (NN, 70/15, 127/17) „azilant je izbjeglica u smislu Konvencije o statusu izbjeglica iz 1951. godine kojoj je priznat azil“ (čl. 4.), a azil se „priznaje tražitelju koji se nalazi izvan zemlje svog državljanstva ili uobičajenog boravišta, a osnovano strahuje od proganjanja zbog svoje rase, vjere, nacionalnosti, pripadnosti određenoj društvenoj skupini ili političkog mišljenja zbog čega ne može ili ne želi prihvatiti zaštitu te zemlje“ (čl. 20.). U razdoblju od 2006. do rujna 2020. godine u Hrvatskoj je odobreno 795 statusa međunarodne zaštite - azila i 142 statusa supsidijarne zaštite. ${ }^{2}$ Pritom je stopa odobravanja statusa azila oko $80 \%$ u odnosu na podnesene zahtjeve. Tražitelji azila u 2019. godini u najvećoj su mjeri dolazili iz Iraka, Afganistana, Sirije, Irana i Alžira te su u većem udjelu muškog spola. Iako se u najvećoj mjeri nastanjuju u većim urbanim centrima, vrlo često nakon odobrenja statusa azilanti napuštaju Hrvatsku. Stoga je slika o njima moderirana većinom preko medija. Mnoga istraživanja usmjerena su na analizu učinka medija na kreiranje stavova o tražiteljima azila i izbjeglicama (npr. Lynn i Lea, 2003.; Georgiou i Zaborowski, 2017.; Gill, 2018.) $)^{3}$, no u ovom se radu taj učinak neće izravno razmatrati, već će se usmjeriti isključivo na stavove i doživljaj tih migrantskih skupina u Hrvatskoj. Novina ovoga rada jest to što se istraživanje provodilo na studentima pravnih fakulteta u $\mathrm{Hr}$ vatskoj, što predstavlja dosad neistraženu dimenziju u ovom području istraživanja. Povod istraživanju stavova upravo te skupine ispitanika nalazimo u tome što će studenti prava kao budući pripadnici pravničkih profesija ${ }^{4}$ biti važni dionici funkcioniranja pravosudnog sustava. To je važno jer se u njegovom okviru nerijetko donose važne od-

1 Prema: http://www.asylumineurope.org/sites/default/files/resources/balkan route reversed.pdf (str. 8-9).

2 Prema podacima Ministarstva unutarnjih poslova RH: https://mup.gov.hr/UserDocsImages/statistika/2020/Me\%C4\%91 unarodna\%20za\%C5\%A1tita/Web\%20statistika\%2001.01.\%20-\%20 30.09.2020..pdf; usp. https://www.asylumineurope.org/reports/country/croatia/statistics

3 O medijskom prikazu tražitelja azila i izbjeglica u Hrvatskoj vidi: Župarić-Iljić (2013.).

${ }^{4} \mathrm{U}$ radu polazimo od pretpostavke da postoji više pravničkih profesija kao što su suci, državni odvjetnici, odvjetnici i javni bilježnici (Schultz i Shaw, 2003.). 
luke koje s jedne strane korigiraju i usmjeravaju postojeće institucionalizirane prakse u okviru drugih društvenih sustava, a s druge izravno utječu na živote i sudbine različitih pojedinaca i skupina u nekom društvu. Neke od tih odluka mogu biti kontroverzne jer se tiču moralnih i političkih pitanja o kojima u društvu često nema suglasnosti (Mrakovčić i Vuković, 2019.:78), a što je u hrvatskom društvu danas vidljivo u kontekstu javnih i političkih rasprava o azilantima i migrantima s Bliskog istoka. U tom smislu, da bi se ostvarila demokratska vladavina prava kao poželjni oblik društvenog uređenja na Zapadu, prema Brianu Tamanahau nužno mora biti zadovoljena/ostvarena vladavina zakona, a ne ljudi, kao jedna od temeljnih karakteristika pravosuđa. Ipak, budući da se zakoni ne mogu sami tumačiti ili primjenjivati, on ističe da su za to potrebni stručnjaci s posebnim moralnim kvalifikacijama, odnosno pravnici koji su obučeni za tako nešto i koji su neovisni od drugih grana vlasti (Tamanaha, 2004.:123-125), pritisaka javnosti i interesnih skupina (op. a.). Stoga, budući da su „pravosuđe, uključujući tijela za provođenje zakona, kao i tijela kaznenog progona i posebno neovisno sudstvo te pravna profesija općenito, u punom suglasju s primjenjivim standardima sadržanih u međunarodnom instrumentariju ljudskih prava, ključni su za puno i ravnopravno ostvarenje ljudskih prava i kao takvi neophodni u procesu demokratizacije i održivog razvoja“" (Međunarodna načela o neovisnosti i odgovornosti sudaca, ..., www.uhs.hr), smatramo važnim istražiti razlikuju li se stavovi studenta prava prema migrantima od stavova opće populacije u našem društvu. Drugim riječima, smatramo da je važno istražiti utječe li i u kojoj mjeri obrazovanje studenata u okviru studija prava na to da oni problematiku migracija i prava migranta percipiraju kroz prizmu nacionalnih i međunarodnih pravnih normi ili te pojave doživljavaju kao i pravni laici iz ostatka hrvatske populacije. ${ }^{5}$ Pravni aspekti i migrantski status tražitelja azila i azilanata/izbjeglica dobro je istraženo područje u Hrvatskoj, o čemu svjedoče mnogi radovi pravne stručnjakinje G. Lalić Novak, čija istraživanja pridonose razjašnjenju i definiranju ovoga pojmovlja vezano ponajprije uz hrvatski zakonodavni okvir (v. npr. Lalić Novak 2010., 2016.; Lalić Novak i Giljević, 2018.). No do koje su mjere studenti prava u Hrvatskoj osvijestili ovaj problem i kakvi su njihovi stavovi prema različitim skupinama migranata pokušalo se saznati istraživanjem provedenim na studentima pravnih fakulteta u Hrvatskoj - u Zagrebu, Rijeci, Splitu i Osijeku, čiji se rezultati ovdje analiziraju.

5 Pojmovi koji se koriste u ovom istraživačkom području nerijetko zbunjuju i studente prava, pri čemu oni ne uspijevaju odrediti razlike između, primjerice, tražitelja azila i izbjeglica (O’Nions, 2014.) ili drugih migranata, što je već dugo vremena nejasno i široj javnosti (Loescher, 1989.). S druge strane, istraživanja su pokazala da ponekad stručnjaci u području prava, pa tako i studenti prava, iako njihova predanost i profesionalizam nisu upitni, možda nisu u potpunosti spremi za rad na razini pravnog sustava zajednice budući da se njihova procjena uspješnog sustava oslanja gotovo isključivo na zakonodavni okvir unutar kojeg su poučavani. To se pokazalo kao ključno prilikom pokušaja jačanja administrativnih kapaciteta i poučavanja o pravnim aspektima u izbjegličkim kampovima na Tajlandu, za što su angažirani upravo pravni stručnjaci i studenti prava (McConnachie, 2014.:118). 
Ciljevi su ovoga rada ispitati stavove studenata pravnih fakulteta o migrantima i azilantima te utvrditi razlike između studenata u poimanju tih skupina s obzirom na neke njihove odabrane karakteristike (sociodemografske, sociokulturne i kontekstualne). Također, u radu se u odnos dovode dvije analizirane skupine stavova: stavovi prema migrantima s Bliskog istoka $(\mathrm{MBI})^{6}$ i stavovi prema azilantima u Republici Hrvatskoj (ARH), pri tom je jedan od ciljeva utvrditi učinak dimenzija percepcije azilanata na stavove o MBI kao potencijalnim tražiteljima azila i azilantima u Hrvatskoj.

\section{Teorijsko-konceptualni okvir $i$ istraživačka pitanja}

Istraživanje stavova prema različitim skupinama migranata vrlo je usustavljeno i sistematizirano multidisciplinarno i interdisciplinarno područje. Već je samo u društvenim znanostima značajan doprinos području vidljiv iz brojnih socioloških i psiholoških studija, u najvećoj mjeri koncentriranih u zemljama zapadne Europe, SAD-a i Australije. Te su studije utemeljene u mnogim teorijskim pristupima, a kao jedno od najučestalijih teorijskih polazišta, poglavito u sociološkim istraživanjima, nalazimo teorije konfliktnog pristupa, tj. teoriju grupne prijetnje (Berg, 2009.) i teoriju integrirane prijetnje (Stephan, Ybarra i Bachman, 1999.). ${ }^{7}$ Važno je istaknuti da se stavovi i stavovske strukture prema nedobrovoljnim i prisilnim migrantima, u koje se ubrajaju tražitelji azila i izbjeglice, vrlo često preklapaju sa stavovima prema regularnim imigrantima i strancima općenito te se očituju u nekoliko dimenzija: kao fizička, tj. sigurnosna i zdravstvena, sociokulturna ili ekonomska prijetnja (usp. Župarić-Iljić i Gregurović, 2013.) $)^{8}$.

Općenito, polazište je teorija grupne prijetnje da dominantna etnička skupina izražava predrasude i negativne stavove prema nekoj drugoj skupini ako osjeti da bi mogla izgubiti svoju društvenu, ekonomsku ili političku moć (Berg, 2009.; Rustenbach, 2010.). U znanstvenoj se literaturi velik naglasak stavlja na interese i identitet skupine, koji predstavljaju glavni temelj za kreiranje stavova prema migrantima. Ti se

${ }^{6}$ Migranti s Bliskog istoka predstavljaju združeni pojam za doseljenike iz zemalja koje su okarakterizirane kao kulturno različite od Hrvatske te koji se u znatnom dijelu preklapaju sa zemljama porijekla tražitelja azila i azilanata u Hrvatskoj. Iako geografski Afganistan (kao zemlja porijekla znatnog broja tražitelja u Hrvatskoj) ne pripada među zemlje Bliskog istoka, često se zbog svog bliskog odnosa s većinskim skupinama iranskih naroda (etnički i religijski) kao i povijesnih veza s Bliskim istokom uključuje u ovu skupinu (usp. https://enciklopedija.hr/natuknica.aspx?ID=8170).

7 Druga teorijska perspektiva koja se učestalo koristi i uspoređuje s konfliktnim pristupom teorija je kontakta (Berg, 2009.; Allport, 1954.; Pettigrew i Tropp, 2005.; Pettigrew i sur., 2011.), no ona se ne razmatra za potrebe ovoga rada.

8 Detaljno konceptualno utemeljenje i operacionalizacija istraživanja uporište imaju u istraživanju Župarić-Iljić i Gregurović (2013.), koji donose pregled teorijskih pristupa i istraživanja korištenih prilikom konstrukcije skale stavova prema tražiteljima azila u Hrvatskoj, a koja je u ovome istraživanju adaptirana za mjerenje stavova prema osobama kojima je status azila odobren. 
stavovi manifestiraju kao doživljaji simbolične ili realistične prijetnje, koji ponajprije ugrožavaju kulturni identitet i ekonomsku stabilnost zemlje primitka (Pereira, Vala i Costa-Lopes, 2009.). Drugim riječima, osjećaj prijetnje koji proizlazi iz objektivnih društvenih i ekonomskih uvjeta ili kulturnih i psiholoških predispozicija nužan je preduvjet za stvaranje negativnih stavova i osjećaja neprijateljstva prema migrantima (Sides i Citrin, 2007.). Konkretno, realistične su prijetnje one koje ugrožavaju fizičko i materijalno blagostanje, ekonomsku i političku moć članova vlastite skupine, a simbolične se prijetnje odnose prvenstveno na pitanja različitih vrijednosti i normi koje članovi vlastite skupine percipiraju u usporedbi s članovima drugih. Pritom se sociopsihološki čimbenici na individualnoj razini pokazuju snažnijima u svom učinku na kreiranje stavova od ekonomskih i demografskih indikatora na razini zemlje (Sides i Citrin, 2007.). Također, istraživanja pokazuju da su prilikom donošenja mišljenja o migrantima važniji duboko ukorijenjeni simbolički stavovi o vlastitoj naciji i identitetu te percipirane kulturne karakteristike i sustav vrijednosti migranata nego ekonomski status, materijalni interesi ili konkurencija na tržištu rada (Sides i Citrin, 2007.; Hainmueller i Hiscox, 2007.). S druge strane, teorija integrirane prijetnje Stephana i sur. (1999.) naglašava da bez obzira na to radi li se o imaginarnoj (simboličnoj) ili stvarnoj (realističnoj) prijetnji, često se te dvije vrste percipirane prijetnje uzimaju zajedno kao čimbenici koji generiraju osjećaj ugroze i povratno mogu utjecati na diskriminirajući odnos prema imigrantima.

Imajući u vidu da tražitelji azila i azilanti/izbjeglice predstavljaju skupnu migranata koji se po svom nepovoljnijem i osjetljivijem položaju razlikuju od drugih skupina migranata, važno je istražiti i do koje su mjere te razlike osviještene u populaciji. Verkuyten, Mepham i Kros (2018.) u svom su istraživanju potvrdili da je među Dancima procjena da je migracija bila prisilna i nedobrovoljna izazvala osjećaj empatije i snažnije podrške pridošlicama u usporedbi s procjenom migracije kao dobrovoljne, što je potaknulo osjećaj bijesa i manje podrške. Učinak javnih diskusija i prezentacija azilanata $\mathrm{u}$ javnom i medijskom prostoru oblikuju stavove javnosti o njima. Iako naglasak u ovome radu nije isključivo na tome, ne može se zanemariti realnost toga efekta. Neki od izraženijih učinaka toga tipa bilježe se uz istraživanja usmjerena na diskurzivne prakse da se tražitelji azila (i azilanti) često kategoriziraju kao prijetnja nacionalnoj sigurnosti i povezuju se s terorističkim aktivnostima, što pridonosi jačanju politika i diskursa „sekuritizacije“ azilnih i migracijskih tokova (Huysmans, 2006.).

Uz procjenu realne, a posebice ekonomske prijetnje mogu se povezati procjene učina$\mathrm{ka}$, tj. koristi i šteta vezanih uz radne migracije, a što je široko istraživana tema. Radne migracije u mnogim su razvijenim (zapadnim) zemljama razmatrane u pozitivnom svjetlu, posebice vezano uz demografski rast populacije (v. npr. Peace, 2019.; Wright i sur. 2016.). Te zemlje također imaju koristi od migranata zbog promjene ponude radne snage, koja dovodi do povećanog povrata kapitala i do drugih proizvodnih čimbenika, a stručnost doseljenika nadopunjuje domaću radnu snagu (Lalonde i Topel, 
1997.). S druge strane, u zemljama jugoistočne Europe istraživanja pokazuju da se imigranti doživljavaju kao čimbenik nepravedne kompeticije domaćim radnicima te teret poreznim obveznicima zbog lošije ekonomske situacije u tim zemljama (usp. Davidov i Semyonov, 2017.). Na primjeru Slovenije (Zavratnik, 2012.) vidljivo je da se u javnosti preferira segmentirani prijem migranata - ovisno o njihovom geografskom i socioekonomskom porijeklu te da se od migranata očekuje svladavanje jezika, adekvatno obrazovanje i zapošljavanje. No procjenu učinaka, tj. koristi i štete od doseljavanja izbjeglica nužno je odvojiti od procjene vezane za regularne radne migracije. Doseljavanje izbjeglica donosi zemljama primitka niz ekonomskih i sigurnosnih rizika, no također i značajan prihod resursa međunarodnih humanitarnih organizacija u obliku pomoći, financijskih prihoda i ljudskog kapitala, kojima, doduše, vlade ne mogu slobodno raspolagati zbog sigurnosnih problema i drugih prepreka (Jacobsen, 2002.). Neka istraživanja upućuju na prednosti i koristi života u blizini izbjegličkih kampova. Rezultati Loschmann, Bilgili i Siegel (2019.) na primjeru Ruande pokazuju da je u blizini izbjegličkog kampa veća vjerojatnost zapošljavanja lokalnog stanovništva, posebice žena, a lokalno stanovništvo u većem udjelu ima vlasništvo nad stambenim nekretninama u krugu od $10 \mathrm{~km}$ od kampa. Ipak, analiza koristi i šteta za društvo primitka vezanih za dolazak migranata i izbjeglica često se u političkim i medijskim diskursima koristi kao sredstvo uvjeravanja javnosti kako o pozitivnim stranama dolaska izbjeglica tako i o negativnim. Prema Zetteru (2012.), rijetke su evaluacije - većinom samo deskriptivne i nepotpune - od vlade i uprave usmjerene na procjenu učinka i troškova za zajednicu primitka, a donatori i NVO većinom su usmjereni na ishode projekata razvoja vještina i stvaranja prihoda ili na financijsku pomoć namijenjenu izbjeglicama. $\mathrm{Ni}$ jedan od tih dvaju pristupa ne donosi „zbirni račun“ makro i mikroekonomskih i fiskalnih učinaka i troškova, a kvantitativne metode i čvrsti empirijski podaci „uočljivi su po njihovoj odsutnosti“" (Zetter, 2012.:50). S druge strane, rezultati ekonomskog istraživanja d'Albis, Boubtane i Coulibaly (2018.) usmjereni na evaluaciju ekonomskih i fiskalnih učinaka dolaska tražitelja azila u zemlje zapadne Europe u razdoblju od 1985. do 2015. godine pokazali su da taj dolazak ne pogoršava ekonomsku situaciju i fiskalnu ravnotežu zemlje primitka jer je povećanje javne potrošnje na azilante više nego dovoljno kompenzirano povećanjem poreznih prihoda transfera. Kako tražitelji azila i izbjeglice postaju stalni stanovnici, njihovi makroekonomski učinci postaju pozitivni. Ipak, sama procjena šire javnosti o koristima i šteti vezanima uz dolazak izbjeglica (koje se ne moraju nužno vezati uz ekonomsku dimenziju), kao i drugi stavovi o njima, većinom ovise o javnoj prezentaciji toga problema.

Sve učestalije metaanalize istraživanja stavova prema migrantima i izbjeglicama potvrđuju učinke određenih sociodemografskih karakteristika ispitanika na njihove stavove prema različitim skupinama migranata (Anderson i Ferguson, 2017.; Cowling, Anderson i Ferguson, 2019.). Najučestalije se pokazuje da su ispitanici muškog spola, stariji, nižeg obrazovanja, politički više konzervativni i s izraženijom nacionalnom identifikacijom u većoj mjeri bili povezivani s negativnim stavovima prema tražiteljima azila 
(Anderson i Ferguson, 2017.; McKay, Thomas i Kneebone, 2012.). Nasuprot tome, viši stupanj obrazovanja i profesionalne vještine u 22 europskim zemljama povezane su $s$ većom podrškom svim oblicima migracije - obrazovaniji su ispitanici značajno manje skloni predrasudama, pridaju veću vrijednost kulturnoj različitosti te također u većoj mjeri vjeruju da imigranti imaju pozitivan učinak na gospodarstvo zemlje primitka (Hainmueller i Hiscox, 2007.). Iako istraživanja pokazuju značajnu povezanost tih indikatora s izraženim stavovima, ta je povezanost slaba ili umjerena. $S$ druge strane, ideološke varijable puno su snažniji korelati, među kojima su najistaknutiji desničarski autoritarizam i orijentacija socijalnoj dominaciji. Antiimigrantski stavovi vezani su i za političku orijentaciju i za općenito izražen interes za politička pitanja, pri čemu lijevo orijentirani i oni zainteresiraniji za politiku izražavaju proimigrantske stavove (Rustenbach, 2010.). Naposljetku, istraživanja su također pokazala da religija može, ovisno o okolnostima, i pojačati i smanjiti predrasude i nesigurnosti prema onima koji nisu članovi zajednice (Karyotis i Patrikios, 2010.).

Uz navedene sociodemografske razlike, važno je uputiti i na neke lokacijske odrednice koje mogu imati učinak na stavove. Istraživanja pokazuju da na mikrolokacijskoj razini, primjerice na razini jednog grada, učinak na stav prema izbjeglicama i tražiteljima azila može imati blizina prihvatnog centra (usp. za Zagreb Gregurović i sur. 2019.; za Nizozemsku Lubbers, Coenders i Scheepers, 2006.). Uz navedeno, regionalne razlike često upućuju na različite pristupe i lokalne političke i ideološke diskurse koji mogu imati učinak na stav javnosti prema izbjeglicama. Rustebach (2010.:67) to povezuje $s$ međusobnim povjerenjem, pri čemu stanovanje u regijama u kojima je međusobno povjerenje visoko može stvoriti pozitivno okružje za prihvaćanje migranata i utjecati na kreiranje pozitivnijih stavova prema njima. Rezultati novijeg istraživanja stavova opće populacije prema izbjeglicama u Hrvatskoj (Ajduković i sur., 2019.) pokazali su pozitivnije stavove stanovnika središnje i primorske regije Hrvatske u odnosu na stanovnike dalmatinske i istočne regije. Navedeno će se pokušati provjeriti i u ovom istraživanju kroz utvrđivanje razlika među pravim fakultetima lociranim u središtima tih regija.

U posljednjih je nekoliko godina porastao interes i doseg istraživanja stavova prema azilantima/izbjeglicama u Hrvatskoj, a posebice nakon tzv. „migrantske/izbjegličke krize“ u 2015./2016. godini. Pri tom je važno uputiti na rezultate istraživanja stavova građana RH (Ajduković i sur., 2019.:95) provedenog na nacionalno reprezentativnom uzorku, prema kojima su stavovi prema izbjeglicama još uvijek neutralni i koji, prema autorima, „imaju potencijal otkloniti se i u pozitivnu i u negativnu stranu“. Ranije spomenuto istraživanje Gregurović i sur. (2019.) bilo je usmjereno ispitivanju učinka kontakta s tražiteljima azila i izbjeglicama te stanovanja u blizini prihvatnog centra na stavove prema izbjeglicama stanovnika dviju gradskih četvrti Grada Zagreba. Medlobi i Čepo (2018.) analiziraju stavove korisnika društvenih mreža o izbjeglicama i tražiteljima azila u razdoblju nakon „izbjegličke krize“ prikupljene online anketom. Druge 
se provedene studije bave ili specifičnim populacijama: npr. istraživanje Župarić-Iljić i Gregurović (2013.) o stavovima studenata Zagrebačkog sveučilišta o tražiteljima azila i istraživanje Gregurović, Kuti i Župarić-Iljić (2016.) koje je provedeno na stanovnicima istočne Hrvatske, ili specifičnom problematikom percepcije smještaja tražitelja azila i gradnje prihvatilišta (Benčić i sur., 2005.; Petrović, 2006.; Petrović i Pozniak, 2014.). Ostala istraživanja usmjerena su stavovima prema migrantima općenito te $u$ najvećoj mjeri upućuju na slične zaključke, prema kojima se migranti u Hrvatskoj percipiraju negativno bilo kao kulturna, ekonomska i/ili sigurnosna prijetnja (Franc i sur., 2010.; Šram, 2010.; Mesić i Bagić, 2011.; Čačić-Kumpes, Gregurović i Kumpes, 2012.).

\subsection{Glavni cilj i istraživačka pitanja}

$\mathrm{Na}$ tragu navedenog teorijskog i kontekstualnog okvira glavni je cilj ovoga istraživanja utvrditi kako studenti pravnih fakulteta u Zagrebu, Rijeci, Osijeku i Splitu procjenjuju ARH te kako su ti stavovi povezani s ukupnom procjenom MBI (ne nužno prisilnih) i procjenom učinka njihova dolaska u Hrvatsku i druge članice EU-a. Istraživačka pitanja od kojih polazimo u analizama su:

1. Kako studenti prava doživljavaju migrante s Bliskog istoka? - uzimajući u obzir i učinak njihova dolaska na Hrvatsku i druge zemlje članice EU-a.

2. Kakvo studenti prava doživljavaju azilante u Hrvatskoj te smatraju li ih prijetnjom? - pritom prijetnju raščlanjujemo na stvarnu i simboličku, tj. ekonomsku, kulturnu, društvenu, sigurnosnu i zdravstvenu.

3. Razlikuju li se studenti prava različitih socioekonomskih, sociokulturnih i drugih odabranih karakteristika (poput poznanstva s migrantima i/ili azilantima) u svojim stavovima prema migrantima s Bliskog istoka i azilantima u Hrvatskoj?

4. Postoji li i koliko je jak učinak percepcije prijetnje koju predstavljaju azilanti u Hrvatskoj na opći stav studenata prava o migrantima s Bliskog istoka?

\section{Metoda}

\subsection{Ispitanici}

Rad se temelji na istraživanju provedenom sredinom 2019. godine na studentima prava na četirima pravnim fakultetima u Hrvatskoj: u Zagrebu, Rijeci, Splitu i Osijeku. ${ }^{9}$ Provedeno je grupno anketno istraživanje u okviru nastave na prvoj i četvrtoj godini studija, pri čemu je cilj bio anketirati između 100 i 150 studenata svake odabrane godine na svakom fakultetu kako bi se omogućile komparacije između mlađih i stari-

\footnotetext{
${ }^{9}$ Za provođenje istraživanja dobivena je suglasnost Etičkog povjerenstva Instituta za migracije i narodnosti.
} 
jih studenata te između različitih fakulteta. Ostvaren je uzorak od 667 ispitanika, pri čemu su detaljnije karakteristike ispitanika prikazane u tablici 1.

Tablica 1.

Struktura uzorka

\begin{tabular}{|l|l|c|c|}
\hline \multicolumn{1}{|c|}{ Varijabla } & Kategorije & N & \% \\
\hline \multirow{4}{*}{ Lokacija Pravnog fakulteta } & Zagreb & 265 & 39,4 \\
\cline { 2 - 4 } & Rijeka & 193 & 28,7 \\
\cline { 2 - 4 } & Split & 119 & 17,7 \\
\cline { 2 - 4 } & Osijek & 95 & 14,1 \\
\hline \multirow{3}{*}{ Godina studija } & 1. & 352 & 52,4 \\
\hline \multirow{3}{*}{ Spol } & 4. & 320 & 47,6 \\
\cline { 2 - 5 } & Ženski & 494 & 73,5 \\
\cline { 2 - 5 } & Muški & 173 & 25,7 \\
\hline
\end{tabular}

Najveći je udio studenata iz Zagreba (gotovo 40\%). Nešto više od četvrtine ih je iz Rijeke, 18\% iz Splita, a 14\% iz Osijeka. Uzorak je ujednačen s obzirom na godinu studija - nešto više od polovice (52\%) studenti su prve godine. Spolna distribucija znatno je otklonjena u korist studentica, kojih je u uzorku gotovo tri četvrtine. Uz navedene karakteristike važno je istaknuti da gotovo polovica ispitanika (48,7\%) ne smatra imovinsko stanje svoje obitelji ni boljim ni lošijim od većine, no gledano $\mathrm{u}$ prosjeku procjenjuju imovinsko stanje obitelji nešto bolje od većine drugih $(\mathrm{M}=3,54$, $\mathrm{SD}=, 692)$. Uzorak je etnički istaknuto homogen (93\% Hrvata).

\subsection{Mjerni instrumenti}

Stavovi studenata pravnih fakulteta ispitivani su u odnosu na MBI te u odnosu na ARH, tj. one koji su u Hrvatskoj ostvarili pravo na međunarodnu zaštitu. Stavovi prema MBI ispitivani su pomoću četiriju nezavisnih tvrdnji kojima se ispituju: 1) vlastiti osjećaji prema migrantima (skala odgovora s pet stupnjeva: od 1 - izrazito negativni do 5 - izrazito pozitivni), 2) procjena štete/koristi od procesa prihvaćanja migranata u zemljama EU-a (skala odgovora s pet stupnjeva: od 1 - izrazito štetio do 5 - izrazito koristio), 3) stav o tome da RH odobri azil migrantima s Bliskog istoka sukladno kvotama EU-a (skala odgovora s pet stupnjeva: od 1 - izrazito se protivim do 5 - izrazito podržavam) i 4) procjena štete/koristi od prihvaćanja migranata s Bliskog istoka $\mathrm{u}$ Hrvatskoj (skala odgovora s pet stupnjeva: od 1 - mnogo više štete nego koristi do 5 - mnogo više koristi nego štete). 
Pri ispitivanju stavova prema ARH upotrijebljen je instrument prethodno testiran na studentima Sveučilišta u Zagrebu (Župarić-Iljić i Gregurović, 2013.) namijenjen ispitivanju stavova prema tražiteljima azila. Instrument je modificiran na način da se umjesto stavova prema tražiteljima azila ispituju stavovi prema azilantima. Korišstena je reducirana inačica instrumenta (29 od 36 tvrdnji), u kojoj su isključene tvrdnje koje se odnose na ispitivanje društvene distance prema azilantima te stavovi o prihvatilištu za tražitelje azila. Uz tvrdnje je bila ponuđena skala odgovora s pet stupnjeva: od 1 - uopće se ne slažem do 5 - u potpunosti se slažem. Nakon provjere uvjeta za provođenje faktorske analize ${ }^{10}$, metodom osnovnih komponenti uz varimax rotaciju i G-K kriterij ispitane su čestice svedene na pet latentnih dimenzija. Dobivene dimenzije poslužile su kao temelj za kreiranje kompozitnih varijabli koje predstavljaju dobivene latentne konstrukte stavova prema azilantima. ${ }^{11}$ Prva dimenzija sastoji se od devet čestica te je zadovoljavajuće pouzdanosti (Cronbachov $\alpha=852$ ). Stavovi u toj dimenziji upućuju na bliskost i kulturnu otvorenost prema azilantima te procjenu slobode azilanata u Hrvatskoj. Druga dimenzija sastoji se od četiriju čestica koje se sadržajno mogu sumirati kao doživljaj azilanata kao zdravstvene i sigurnosne prijetnje (Cronbachov $\alpha=, 800$ ). Treća dimenzija sastoji se od šest čestica čiji sadržaj upućuje na procjenu da azilanti ne predstavljaju prijetnju kulturi, identitetu, ekonomiji i sigurnosti (Cronbachov $\alpha=, 766$ ). Četvrtu dimenziju tvore tri čestice te je nešto slabije no prihvatljive pouzdanosti (Cronbachov $\alpha=651$ ), a sadržajno je orijentirana na željeni profil azilanata. Posljednja, peta dimenzija sastoji se samo od dviju čestica ${ }^{12}$ koje su usmjerene na procjenu vjerodostojnosti azilanata. Iako je ta dimenzija nešto slabije unutarnje pouzdanosti (Cronbachov $\alpha=520$ ), razlog za njezino zadržavanje u analizama je taj što ni jedna druga čestica nije korištena za mjerenje tog aspekta, a zadržana je mogućnost komparacije s drugim istraživanjima o stavovima prema azilantima u Hrvatskoj (vidi Gregurović i sur., 2019.).

Uz navedene indikatore kojima se mjere stavovi prema MBI i ARH u radu se još analizira niz pitanja koja služe kao deskriptivni i kontekstualni pokazatelji za koje potencijalno postoji vjerojatnost da su povezani sa spomenutim stavovima. Ovi se indikatori mogu podijeliti u tri skupine: 1) sociodemografske karakteristike ispitanika (spol, veličina mjesta prebivališta, grad i godina studija, procjena imovinskog stanja obitelji), 2) sociokulturne karakteristike ispitanika (politička orijentacija, religijska

\footnotetext{
${ }^{10}$ Kaiser-Meyer-Olkin Measure of Sampling Adequacy = 0,926; Bartlett's Test of Sphericity = 4562,059. 11 Sadržaj čestica i njihovi deskriptivni pokazatelji nalaze se u tablici u Prilogu 1.

12 Kriterij za zadržavanje faktora koji se sastoji od dviju čestica jest njihova visoka međusobna korelacija $(r>0,7)$ i niska ili nepostojeća korelacija s drugim česticama (Yong i Pearce, 2013.; Worthington i Whittaker, 2006.). Imajući u vidu da se u cijelom instrumentu korelacije između čestica kreću do maksimalno $\mathrm{r}$ $=, 575$, korelacija između ove dvije varijable $(\mathrm{r}=, 352, \mathrm{p}=, 000)$ procijenjena je kao zadovoljavajuće visine, pri čemu s drugim česticama ove varijable ne bilježe veću, a često ni statistički značajnu korelaciju.
} 
samoidentifikacija ${ }^{13}$ ) i 3) kontekstualni pokazatelji (osobno ili obiteljsko iskustvo raseljenosti, prijatelji stranci u RH, poznavanje tražitelja azila ili azilanta). Moguće kategorije odgovora prikazane su u tablicama u Prilozima 2 i 3.

\subsection{Analize}

U radu je primijenjen niz univarijatnih, bivarijatnih i multivarijatnih analiza provedenih u programskom paketu SPSS 18.0. Univarijatne analize uključuju deskriptivne analize na razini pojedinih čestica, a koje se nalaze u tablici u prilogu ovoga rada. Bivarijatnim analizama dovedene su u odnos odabrane zavisne varijable i nezavisni indikatori sociodemografskih, sociokulturnih i kontekstualnih karakteristika ispitanika. Uz provedene korelacijske analize, t-testom i analizom varijance ${ }^{14}$ testirane su razlike u stavovima prema MBI i ARH između ispitanika različitih karakteristika. Kao zavisni pokazatelji stavova prema ARH upotrijebljene su kompozitne varijable kreirane na temelju faktorske analize. Uz spomenutu faktorsku, u radu je primijenjena i multivarijatna regresijska analiza kako bi se ispitao učinak stavova prema ARH (prediktori) na percepciju MBI kao kriterijskih varijabli.

\section{Rezultati}

Stavovi prema MBI i azilantima u Hrvatskoj ispitivani su odvojenim mjernim instrumentima te prvo donosimo njihove osnovne deskriptivne pokazatelje. Kao što je vidljivo iz tablice 2, prosječni odgovori ispitanika na sva pitanja o MBI nalaze se ispod teorijskog prosjeka skale. U slučaju triju varijabli broj onih koji imaju negativan stav (kategorije 1 i 2) prema analiziranim pitanjima znatno je veći od broja onih koji imaju pozitivan stav (kategorije 4 i 5). U jednom je slučaju udio ispitanika s negativnim, neutralnim i pozitivnim stavom podjednak. Iako više od pola ispitanika ističe kako ne veže ni negativne ni pozitivne osjećaje uz MBI koji pokušavaju doći u EU zadnjih godina, broj onih koji s tim migrantima povezuju negativne osjećaje tri puta je veći od onih koji uz njih vežu pozitivne. Još nešto negativniji stav ispitanici imaju pri procjeni šteta i koristi koje bi proces prihvaćanja migranta mogao općenito gledano donijeti zemljama primateljicama iz EU-a. Gotovo je deset puta više onih ispitanika koji smatraju da će taj proces zemljama štetiti od onih koji smatraju da će im koristiti. Pri procjeni mogućih koristi ili šteta u slučaju da Republika Hrvatska odobri azil i ostanak određenom broju MBI nalazimo dvostruko više onih ispitanika s negativnim od onih

13 Kategorije varijable religijske samoidentifikacije preuzete su iz istraživanja „Društvene i religijske promjene u Hrvatskoj“ Instituta za društvena istraživanja u Zagrebu (Marinović Jerolimov, 2005.).

${ }^{14}$ Za svaku analizu varijance proveden je test homogenosti varijance, testiran F-omjer te su provedeni post-hoc testovi multiple komparacije. U slučaju homogenih varijanci korišten je Scheffeov, a u slučaju nehomogenih Tamhaneov T2 test. 
s pozitivnim stavom. Zanimljivo je primijetiti da se u odnosu na prethodna pitanja situacija donekle mijenja u kontekstu stava o tome da Republika Hrvatska, sukladno kvotama EU-a ${ }^{15}$, odobri azil i ostanak određenom broju MBI. Naime, trećina se ispitanika tome protivi, trećina to podržava, a trećina je neodlučna.

Tablica 2.

Stavovi prema migrantima s Bliskog istoka

\begin{tabular}{|c|c|c|c|c|c|c|c|}
\hline & & & & & & $\mathbf{N}$ & $\underset{\text { (SD) }}{M}$ \\
\hline \multirow{2}{*}{$\begin{array}{l}\text { Kakve osjećaje Vi osobno } \\
\text { vezujete uz migrante koji } \\
\text { zadnjih godina s Bliskog } \\
\text { istoka pokušavaju doći u } \\
\text { EU? }\end{array}$} & $\begin{array}{c}\text { Izrazito } \\
\text { negativne }\end{array}$ & $\begin{array}{l}\text { Uglavnom } \\
\text { negativne }\end{array}$ & $\begin{array}{c}\text { Ni negativne } \\
\text { ni pozitivne }\end{array}$ & $\begin{array}{l}\text { Uglavnom } \\
\text { pozitivne }\end{array}$ & $\begin{array}{c}\text { Izrazito } \\
\text { pozitivne }\end{array}$ & \multirow{2}{*}{653} & \multirow{2}{*}{$\begin{array}{c}2,69 \\
(, 781)\end{array}$} \\
\hline & $6,7 \%$ & $29,4 \%$ & $53,0 \%$ & $9,8 \%$ & $1,1 \%$ & & \\
\hline \multirow{2}{*}{$\begin{array}{l}\text { Ukupno gledajući, } \\
\text { mislite li da je zemljama } \\
\text { primateljicama iz Europske } \\
\text { unije proces prihvaćanja } \\
\text { migranta: }\end{array}$} & Izrazito štetio & $\underset{\text { štetio }}{\text { Uglavnom }}$ & \begin{tabular}{|c|} 
Donio \\
podjednako \\
štete i koristi
\end{tabular} & $\begin{array}{l}\text { Uglavnom } \\
\text { koristio }\end{array}$ & $\begin{array}{l}\text { Izrazito } \\
\text { koristio }\end{array}$ & \multirow{2}{*}{670} & \multirow{2}{*}{$\begin{array}{r}2,48 \\
(, 745\end{array}$} \\
\hline & $9,1 \%$ & $39,3 \%$ & $46,4 \%$ & $4,8 \%$ & $0,4 \%$ & & \\
\hline \multirow{2}{*}{$\begin{array}{l}\text { Kakav je Vaš stav o tome } \\
\text { da Republika Hrvatska, } \\
\text { sukladno kvotama EU- } \\
\text { a, odobri azil i ostanak } \\
\text { određenom broju migranta } \\
\text { s Bliskog istoka? }\end{array}$} & $\begin{array}{c}\text { Izrazito se } \\
\text { protivim } \\
\text { tome }\end{array}$ & $\begin{array}{l}\text { Uglavnom } \\
\text { se protivim } \\
\text { tome }\end{array}$ & $\begin{array}{c}\text { Neodlučan/ } \\
\text { na sam }\end{array}$ & $\begin{array}{l}\text { Uglavnom } \\
\text { podržavam }\end{array}$ & $\begin{array}{c}\text { Izrazito } \\
\text { podržavam }\end{array}$ & \multirow{2}{*}{670} & \multirow{2}{*}{$\begin{array}{c}2,98 \\
(1,07)\end{array}$} \\
\hline & $9,6 \%$ & $23,0 \%$ & $33,0 \%$ & $28,5 \%$ & $6,0 \%$ & & \\
\hline \multirow{2}{*}{$\begin{array}{l}\text { Odobri li Republika } \\
\text { Hrvatska azil i ostanak } \\
\text { određenom broju migranta } \\
\text { s Bliskog istoka, hoće li joj } \\
\text { to po Vama donijeti: }\end{array}$} & \begin{tabular}{|c|} 
Mnogo više \\
štete nego \\
koristi
\end{tabular} & $\begin{array}{c}\text { Nešto više } \\
\text { štete nego } \\
\text { koristi }\end{array}$ & $\begin{array}{l}\text { Podjednako } \\
\text { štete i koristi }\end{array}$ & $\begin{array}{c}\text { Nešto više } \\
\text { koristi nego } \\
\text { štete }\end{array}$ & \begin{tabular}{|c} 
Mnogo više \\
koristi nego \\
štete
\end{tabular} & \multirow{2}{*}{669} & \multirow{2}{*}{$\begin{array}{c}2,66 \\
(1,01)\end{array}$} \\
\hline & $16,0 \%$ & $23,2 \%$ & $42,6 \%$ & $15,5 \%$ & $2,7 \%$ & & \\
\hline
\end{tabular}

Distribucije rezultata i prosječne vrijednosti ispitanika na kompozitnim varijablama vezanim uz stavove studenata o ARH koje su utemeljene na provedenoj faktorskoj analizi prikazane su u grafu $1 .{ }^{16}$ Što se tiče prvog konstrukta, odnosno stavova o kulturnoj otvorenosti, potencijalnoj društvenoj bliskosti prema azilantima i pitanju slobode izražavanja i kretanja azilanata prikazani odgovori ispitanika tendiraju iznad teorijskog prosjeka skale. Ispitanici u prosjeku ističu da bi pomogli azilantu ukoliko im se ukaže prilika, da bi razgovarali s azilantom koji bi ih zaustavio na ulici. Slažu se s tim da bi azilanti trebali imati pravo slobodno izražavati svoje običaje i tradicije te pravo

\footnotetext{
15 Kvote EU-a odnose se na kvote iz Europskog programa preseljenja [i premještanja] izbjeglica (Resettlement and Relocation) u kojem sudjeluje i Republika Hrvatska prema Preporuci Komisije (EU) 2015/914 od 8. lipnja 2015. o Europskom programu preseljenja, C/2015/3560, OJ L 148, 13.6.2015, p. 32-37.

16 Postupak faktorske analize opisan je u poglavlju Metode, a distribucije rezultata, aritmetičke sredine, standardne devijacije i zasićenja pojedinačnih varijabli na pripadajućem faktoru prikazane su u tablici u Prilogu 1.
} 
slobodno se kretati po Republici Hrvatskoj kao i da bi se kultura azilanata trebala miješati s hrvatskom kulturom. Uz to, ističu da bi podržali ideju da član njihove obitelji koji ide u školu koju pohađa i dijete azilant na dopunskoj nastavi uči jezik azilanta. Kompozitna varijabla koja predstavlja faktor percepcije azilanata kao zdravstvene i sigurnosne prijetnje pokazuje da ispitanici u prosjeku ne smatraju da su azilanti kriminalci, prikriveni teroristi ili prenositelji opasnih bolesti. S druge strane, kada se analizira sljedeći konstrukt, prema kojem azilanti u Hrvatskoj ne predstavljaju prijetnju kulturi, identitetu ekonomiji i sigurnosti, vidljivo je da se ispitanici u prosjeku grupiraju oko sredine skale, koja upućuje na neutralnost prilikom donošenja procjena. Drugim riječima, ispitanici su umjereni u svojim procjenama azilanata kao izvora navedenih vrsta prijetnje, iako na razini pojedinih čestica (Prilog) zapravo azilante ne doživljavaju kao posebnu prijetnju za hrvatsku kulturu, nacionalno jedinstvo ili stabilnost političkog poretka. Ipak, sukladno istim nalazima skloniji su smatrati da bi azilanti mogli predstavljati opterećenje za porezne obveznike, biti teret za ekonomski razvoj zemlje te biti sigurnosni problem za zajednicu gdje bi bili smješteni. Što se tiče "poželjnog“ profila azilanata kao četvrtog nezavisnog konstrukta, anketirani se studenti u prosjeku ne slažu da bi azilanti koji dolaze u RH trebali biti slični domicilnom stanovništvu po boji kože. Slično tome, ne smatraju ni da je poželjno da u RH zatraže azil samo ljudi iz razvijenijih zemalja ili oni koji su po svojoj etničkoj pripadnosti slični hrvatskom stanovništvu. S druge strane, na posljednjem, petom konstruktu percepcije vjerodostojnosti ARH ispitanici u prosjeku smatraju da su oni zapravo prikriveni ekonomski migranti koji u Europu dolaze u potrazi za zaradom i boljim životom.

Graf 1.

Stavovi prema azilantima u RH - dimenzije prema faktorskoj analizi

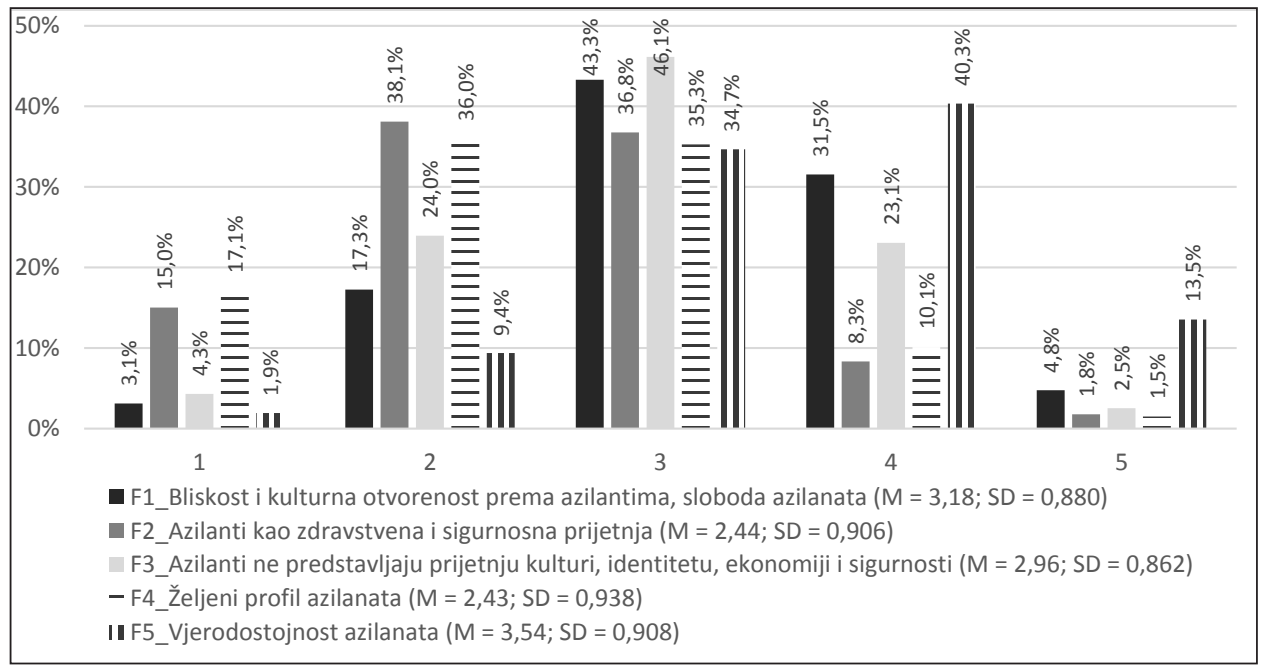


Kako bi se utvrdile razlike u stavovima prema MBI i ARH s obzirom na sociodemografske i sociokulturne karakteristike ispitanika te prema odabranim kontekstualnim pokazateljima, proveden je niz analiza (t-test i ANOVA) (tablice u prilozima 2 i 3 ). Kao sociodemografske varijable analizirani su spol, veličina mjesta prebivališta, grad i godina studija, procjena imovinskog stanja obitelji, kao sociokulturne karakteristike upotrijebljene su politička orijentacija i religijska samoidentifikacija, a kao kontekstualni pokazatelji analizirani su osobno ili obiteljsko iskustvo raseljenosti, prijatelji stranci u RH, poznavanje tražitelja azila ili azilanta.

Rezultati analize varijance pokazuju da studenti kojima je mjesto prebivališta u Zagrebu izražavaju prosječno veću podršku da RH, sukladno europskim kvotama, odobri azil i ostanak određenom broju MBI od studenata koji imaju prebivalište u gradovima s više od 35.000 stanovnika. ${ }^{17}$ Analiza varijance pokazala je da postoji statistički značajna razlika $s$ obzirom na mjesto prebivališta i stav studenata vezano uz štete/koristi koje bi odobravanje azila spomenutim migrantima imalo za RH. Ipak, post-hoc testovi u ovom slučaju nisu pokazali značajnost razlika ni među jednom skupinom.

Studenti koji studiraju u Splitu i Osijeku u prosjeku su više skloni protiviti se odobravanju azila MBI u RH od studenta iz Zagreba i Rijeke, čiji je prosječni stav po tom pitanju neutralan do blago pozitivan. Uz to, studenti iz Splita prosječno u većoj mjeri od studenta iz Zagreba i Rijeke smatraju da bi odobravanje azila tim migrantima štetilo RH. Također se pokazalo da studenti četvrte godine u prosjeku imaju negativnije stavove od studenta prve godine na svim četirima varijablama stavova o migrantima.

Zanimljivo je da i studenti koji procjenjuju da je imovinsko stanje njihovih obitelji znatno lošije od većine drugih i studenti koji procjenjuju da je imovinsko stanje njihovih obitelji znatno bolje od većine drugih prosječno u većoj mjeri procjenjuju da bi odobravanje azila MBI štetilo zemljama primateljicama iz EU-a od studenta koji imovinsko stanje svojih obitelji procjenjuju kao ni bolje ni lošije od većine drugih ili kao nešto bolje od većine drugih.

Nadalje, razlike prema političkoj orijentaciji pokazuju da studenti prava koji se identificiraju $s$ desnicom i desnim centrom imaju u prosjeku negativnije osjećaje prema $\mathrm{MBI}$, više se protive tome da RH tim migrantima odobri azil te u većoj mjeri smatraju da bi odobravanje azila tim osobama štetilo RH ili drugim zemljama primateljicama u EU-u od ispitanika koji se identificiraju s političkim centrom, lijevim centrom ili lje-

\footnotetext{
17 Rezultati provedenih analiza (t-test i ANOVA) na stavovima prema MBI prikazani su u Prilogu 2 zajedno s deskriptivnim podacima nezavisnih varijabli.
} 
vicom. Pored toga, oni koji se identificiraju s desnicom statistički se značajno razlikuju i od ispitanika koji se identificiraju s desnim centrom vezano uz osjećaje koje imaju prema migrantima i vezano uz procjenu štete koju bi odobravanje azila migrantima imalo za RH.

Analize su utvrdile razlike i s obzirom na religijsku samoidentifikaciju ispitanika. Ispitanici koji se određuju kao uvjereni vjernici koji prihvaćaju sve što njihova religija uči i oni koji su religiozni, ali ne prihvaćaju sve što njihova religija uči imaju prosječno negativnije osjećaje prema MBI od ispitanika koji tvrde da nisu religiozni, ali nemaju ništa protiv religije, a koji prema migrantima u prosjeku imaju neutralne osjećaje. Pored toga, ispitanici koji nisu vjernici, ali nemaju ništa protiv religije u prosjeku se statistički značajno razlikuju od ispitanika koji se identificiraju kao uvjereni vjernici ili kao religiozni s obzirom na stav o tome treba li RH odobriti azil određenom broju MBI. Prvi u prosjeku tendiraju odobravanju azila tim migrantima u RH, a drugi se u prosjeku tome protive.

Konačno, pokazalo se da između studenata i studentica nema statistički značajne razlike ni prema jednoj varijabli koja mjeri stavove prema MBI. Isto se pokazalo u odnosu na kontekstualne pokazatelje: ispitanici koji imaju osobno ili obiteljsko prognaničko ili izbjegličko iskustvo, oni koji su upoznali tražitelja azila ili azilanta i oni koji imaju prijatelja „stranca“ (ne-državljana RH) statistički se značajno ne razlikuju ni po jednom stavu od onih ispitanika koji nemaju takva iskustva.

Isti niz analiza primijenjen je i na dobivene dimenzije stavova prema azilantima. ${ }^{18}$ Rezultati t-testa i analize varijance pokazuju da su studenti u prosjeku spremniji na nešto veću društvenu bliskost i kulturnu otvorenost prema azilantima od studentica. Istovremeno, studenti se prosječno još nešto više od studentica ne slažu s time da je poželjno da ARH budu nužno slični domicilnom stanovništvu po boji kože, etničkoj pripadnosti ili da dolaze samo iz razvijenijih zemalja.

Nadalje, pokazalo se da studenti kojima je mjesto prebivališta u Zagrebu izražavaju u prosjeku nešto veću društvenu bliskost i kulturnu otvorenost prema ARH te da ih u manjoj mjeri doživljavaju kao zdravstvenu ili sigurnosnu prijetnju od studenata s prebivalištem u gradovima s više od 35.000 stanovnika i gradovima s 10.000 do 35.000 stanovnika. Također, prva se skupina značajno razlikuje od drugih dviju skupina ispitanika i s obzirom na procjenu da azilanti ne predstavljaju prijetnju za hrvatsku kulturu, identitet, ekonomiju i političku stabilnost.

18 Rezultati provedenih analiza (t-test i ANOVA) na stavovima prema ARH prikazani su u Prilogu 3 zajedno s deskriptivnim podacima nezavisnih varijabli. 
Analize su pokazale da su studenti koji studiraju u Zagrebu i Rijeci u prosjeku spremni na nešto veću kulturnu otvorenost i društvenu bliskost prema ARH od studenta iz Osijeka i Splita. Studenti iz Zagreba također prosječno u većoj mjeri od studenta iz Osijeka i Splita ne smatraju da su azilanti zdravstvena i sigurnosna prijetnja za hrvatsko društvo. Istu značajnu razliku nalazimo i između studenta iz Rijeke i Osijeka. S druge strane, studenti iz Splita i Osijeka prosječno se više ne slažu s tim da ARH ne predstavljaju prijetnju hrvatskoj kulturi, identitetu, ekonomiji i sigurnosti od studenta iz Zagreba, koji su po tom pitanju neutralni ka blago pozitivni. Istu situaciju nalazimo i između studenta iz Splita i Rijeke. Pored toga, studenti iz Zagreba u prosjeku se statistički značajno više od studenta iz Splita ne slažu s tim da je „poželjno“ da ARH budu „rasno“ i etnički slični domicilnom stanovništvu. Konačno, studenti iz Osijeka prosječno u većoj mjeri od studenta iz Rijeke smatraju da su azilanti koji u ovom trenutku dolaze u Europu zapravo prikriveni ekonomski migranti, a ne prave izbjeglice.

Razlike prema političkoj orijentaciji pokazuju da su studenti koji se identificiraju s desnicom i desnim centrom u prosjeku manje skloni podržavati kulturnu otvorenost i društvenu bliskost prema ARH od studenta koji se identificiraju s lijevim centrom ili ljevicom. Pored toga, ispitanici koji se identificiraju s desnicom prosječno su manje otvoreni prema azilantima od onih koji se identificiraju s centrom, a oni koji se identificiraju s centrom manje od onih koji se identificiraju s lijevim centrom. Nadalje, ispitanici koji se identificiraju s ljevicom, lijevim centrom, centrom pa i desnim centrom u prosjeku statistički značajno u manjoj mjeri ARH percipiraju kao zdravstvenu i sigurnosnu prijetnju od onih koji se identificiraju s desnicom. Uz to, po tom se pitanju i oni koji se identificiraju s desnim centrom statistički značajno razlikuju od onih koji se identificiraju s ljevicom i lijevim centrom. Ispitanici koji se identificiraju s desnicom i desnim centrom tendiraju se ne slagati s time da ARH ne predstavljaju prijetnju za hrvatsku kulturu, identitet te ekonomiju i političku stabilnost RH, za razliku od ispitanika centra, lijevog centra i ljevice, koji vezano uz to tendiraju odgovorima iznad teorijskog prosjeka skale. Po tom pitanju statistički značajne razlike postoje još između onih koji se identificiraju s desnicom i onih koji se identificiraju s desnim centrom, te onih koji se identificiraju s centrom i onih koji se identificiraju s lijevim centrom. $\mathrm{Uz}_{\mathrm{z}}$ navedeno, ispitanici koji se identificiraju s ljevicom, lijevim centrom i centrom u većoj se mjeri u prosjeku ne slažu od onih koji se identificiraju s desnicom i desnim centrom da bi bilo dobro da ARH budu „rasno“ i etnički slični domicilnom stanovništvu. Konačno, ispitanici koji se identificiraju s ljevicom prosječno u značajno manjoj mjeri od ispitanika koji se identificiraju s centrom, desnim centrom i desnicom smatraju da azilanti koji dolaze u EU nisu vjerodostojni.

Analize su utvrdile razlike s obzirom na religijsku samoidentifikaciju ispitanika na svim dimenzijama stavova prema ARH. Pokazalo se da su ispitanici koji tvrde da 
nisu religiozni, ali nemaju ništa protiv religije u prosjeku spremni na veću kulturnu i društvenu otvorenost prema azilantima te da u većoj mjeri smatraju da azilanti ne predstavljaju prijetnju za hrvatsku kulturu, identitet, ekonomiju i političku stabilnost od ispitanika koji se identificiraju kao uvjereni vjernici i prihvaćaju sve što njihova religija uči i onih koji su religiozni, ali ne prihvaćaju sve što njihova religija uči. Također se i ispitanici koji nisu religiozni te su protivnici religije i oni koji nisu načisto vjeruju li ili ne vjeruju prosječno u većoj mjeri od uvjerenih vjernika ne slažu s tim da ARH predstavljaju prijetnju za kulturu, identitet, ekonomiju i političku stabilnost hrvatskog društva. Pored toga, ispitanici koji nisu religiozni, ali nemaju ništa protiv religije u većoj se mjeri od uvjerenih vjernika i religioznih ne slažu s tim da ARH predstavljaju zdravstvenu i sigurnosnu prijetnju za hrvatsko društvo. Uz navedeno, i ispitanici koji nisu načisto vjeruju li ili ne vjeruju prosječno u manjoj mjeri od uvjerenih vjernika doživljavaju ARH kao zdravstvenu i sigurnosnu prijetnju. Nadalje, pokazalo se da se u prosjeku ispitanici koji nisu vjernici te su protivnici religije i ispitanici koji nisu vjernici, ali nemaju ništa protiv religije statistički značajno u većoj mjeri od uvjerenih vjernika ne slažu s time da bi bilo poželjno da ARH budu „rasno“ i etnički slični domicilnom stanovništvu. Konačno, post-hoc testovi nisu pokazali značajnost razlika između skupina ispitanika s obzirom na religijsku samoidentifikaciju po pitanju stava o „vjerodostojnosti“ azilanata.

Uz navedeno, t-testovi su pokazali da su studenti koji su upoznali tražitelja azila ili azilanta u prosjeku spremni na veću kulturnu otvorenost i društvenu bliskost od ispitanika koji nisu imali takvo iskustvo. Pored toga, prvi se u još većoj mjeri od drugih ne slažu s time da ARH predstavljaju zdravstvenu i sigurnosnu prijetnju za hrvatske građane. Studenti koji imaju prijatelja ili prijatelje strance koji žive u RH u prosjeku su spremniji na nešto veću otvorenost i bliskost prema azilantima od ispitanika koji takvih prijatelja nemaju. Prvi se također u većoj mjeri od drugih ne slažu s time da bi bilo poželjno da ARH „rasno“ i etnički budu slični hrvatskom stanovništvu. Važno je istaknuti da su studenti koji su imali osobno ili obiteljsko iskustvo raseljenosti u većoj mjeri od onih koji nisu imali takvo iskustvo skloni ARH smatrati ekonomskim migrantima u potrazi za boljim životom.

Naposljetku, analize su pokazale da između skupina studenata s različitim procjenama obiteljskog socioekonomskog statusa i studenata s različitih godina studija ne postoje statistički značajne razlike s obzirom na stavove o ARH.

Posljednja je od primijenjenih analiza multipla regresija, kojom se želi ispitati učinak stavova i percepcije ARH na općeniti stav koji studeni imaju prema MBI kao potencijalnim tražiteljima azila i azilantima u Hrvatskoj i Europskoj uniji (tablica 3). 
Tablica 3.

Regresijska analiza - učinak stavova o azilantima u RH na stav prema migrantima s Bliskog istoka

\begin{tabular}{|c|c|c|c|c|}
\hline & $\begin{array}{c}\text { Kakve osjećaje Vi } \\
\text { osobno vezujete } \\
\text { uz migrante koji } \\
\text { zadnjih godina } \\
\text { s Bliskog istoka } \\
\text { pokušavaju doći } \\
\text { u EU? }\end{array}$ & $\begin{array}{l}\text { Ukupno gledajući, } \\
\text { mislite li da } \\
\text { je zemljama } \\
\text { primateljicama } \\
\text { iz Europske } \\
\text { unije proces } \\
\text { prihvaćanja } \\
\text { migranta štetito/ } \\
\text { koristio? }\end{array}$ & $\begin{array}{c}\text { Kakav je Vaš } \\
\text { stav o tome } \\
\text { da Republika } \\
\text { Hrvatska, } \\
\text { sukladno kvotama } \\
\text { EU-a, odobri } \\
\text { azil i ostanak } \\
\text { određenom } \\
\text { broju migranta s } \\
\text { Bliskog istoka? } \\
\end{array}$ & $\begin{array}{c}\text { Odobri li } \\
\text { Republika } \\
\text { Hrvatska azil } \\
\text { i ostanak } \\
\text { određenom } \\
\text { broju migranta s } \\
\text { Bliskog istoka, } \\
\text { hoće li joj to po } \\
\text { Vama donijeti } \\
\text { štetu/korist? }\end{array}$ \\
\hline & Stand. $\beta$ & Stand. $\beta$ & Stand. $\beta$ & Stand. $\beta$ \\
\hline $\begin{array}{l}\text { Bliskost i kulturna } \\
\text { otvorenost prema } \\
\text { azilantima, sloboda } \\
\text { azilanata }\end{array}$ &, $484^{* * *}$ &, $437^{* * *}$ &, $502^{* * *}$ &, $472^{* * *}$ \\
\hline $\begin{array}{l}\text { Azilanti kao zdravstvena } \\
\text { i sigurnosna prijetnja }\end{array}$ &,$- 247^{* * *}$ &,$- 154^{* * *}$ &,$- 305^{* * *}$ &,$- 259^{* * *}$ \\
\hline $\begin{array}{l}\text { Azilanti ne predstavljaju } \\
\text { prijetnju kulturi, } \\
\text { identitetu, ekonomiji i } \\
\text { sigurnosti }\end{array}$ &, $327^{* * *}$ &, $313^{* * *}$ &, $366^{* * *}$ &, $399^{* * *}$ \\
\hline Željeni profil azilanata &,$- 177^{* * *}$ &,$- 095^{* *}$ &,$- 211^{* * *}$ &,$- 172^{* * *}$ \\
\hline $\begin{array}{l}\text { Vjerodostojnost } \\
\text { azilanata }\end{array}$ &,$- 078^{* *}$ &,$- 099^{* * *}$ &,$- 114^{* * *}$ &,$- 080^{* *}$ \\
\hline Adjusted $\mathbf{R}^{2}$ & ,441 & ,326 &, 532 & ,481 \\
\hline & $\mathrm{F}=88,392 \mathrm{p}<, 000$ & $\begin{array}{c}\mathrm{F}=56,131 \\
\mathrm{p}<, 000\end{array}$ & $\begin{array}{c}\mathrm{F}=130,523 \\
\mathrm{p}<, 000\end{array}$ & $\begin{array}{c}\mathrm{F}=106,715 \\
\mathrm{p}<, 000\end{array}$ \\
\hline
\end{tabular}

${ }^{* * *} \mathrm{p}<0,001,{ }^{* *} \mathrm{p}<0,01$

Kao zavisne varijable korištene su četiri jednostavne čestice koje ispituju stavove ispitanika o potencijalnim štetama/koristima koje bi prihvaćanje MBI moglo imati za EU i Republiku Hrvatsku, o protivljenju/podršci odobravanja azila tim migrantima u RH te osjećajima (negativnim/pozitivnim) koje vezuju uz migrante koji pokušavaju doći u EU zadnjih godina. Kao prediktori u modelu korišteni su faktori dobiveni ranije opisanom faktorskom analizom primijenjenom na višedimenzionalnoj skali stavova o ARH. Pokazalo se da prediktori upotrjebljeni u ovom modelu zajedno tumače zado- 
voljavajući postotak varijance kriterijskih varijabli, od 32,6\% do 53,2\%, pri čemu model u najvećem udjelu tumači stav o tome da Republika Hrvatska, sukladno kvotama EU-a, odobri azil i ostanak određenom broju MBI, dok u najmanjem udjelu tumači procjenu štete/koristi od prihvaćanja migranata u drugim zemljama primateljicama u EU-u. Prediktorska varijabla koja reprezentira bliskost i kulturnu otvorenost prema ARH te stav o slobodi kretanja i izražavanja kulture azilanata u svim se slučajevima pokazala kao prediktor koji najsnažnije tumači stavove prema MBI. S druge strane, prediktor koji reprezentira stavove o „(ne)vjerodostojnosti“ azilanata u svim slučajevima najslabije tumači varijance kriterijskih varijabli. Pokazalo se i to da su prediktori koji reprezentiraju bliskost i kulturnu otvorenost prema ARH te procjenu da ARH ne predstavljaju prijetnju kulturi, identitetu, ekonomiji i sigurnosti zemlje u koju dolaze pozitivno povezani sa svim kriterijskim varijablama. Istovremeno, prediktori koji reprezentiraju percepciju ARH kao zdravstvene ili sigurnosne prijetnje za zajednicu u koju dolaze, stav o njima kao prikrivenim ekonomskim migrantima koji u EU dolaze u potrazi za zaradom i boljim životom te stav o tome da bi bilo dobro da $\mathrm{u}$ RH dolaze azilanti samo iz razvijenih zemalja te da budu slične boje kože ili etničke pripadnosti kao domicilno stanovništvo u svim su slučajevima negativno povezani s kriterijskim varijablama.

U kontekstu emocija koje studenti prava gaje prema migrantima koji zadnjih godina s Bliskog istoka pokušavaju doći u EU pokazalo se da pozitivnije osjećaje prema njima imaju oni ispitanici koji su kulturno otvoreniji i spremniji na veću društvenu bliskost i slobodu kretnja i izražavanja ARH te oni koji se više slažu s tim da ARH ne predstavljaju prijetnju za hrvatsku kulturu i identitet, teret za ekonomski razvoj, ugrozu za stabilnost političkog poretka RH ili sigurnosnu prijetnju za zajednicu u kojoj su smješteni. Istovremeno, negativnije osjećaje prema njima imaju oni ispitanici koji ARH doživljavaju kao zdravstvenu i sigurnosnu prijetnju za zajednicu, oni koji bi željeli da ARH budu bojom kože ili etničkim karakteristikama slični hrvatskom stanovništvu i oni koji smatraju da azilanti nisu prave izbjeglice, već prikriveni ekonomski migranti u potrazi za boljim životom. Kad se analizira stav o štetama/koristima koje bi za zemlje primateljice iz EU-a imao proces prihvaćanja migranta s Bliskog istoka prediktivna moć odabranih prediktora nešto je slabija nego u prethodnom slučaju. Ipak, ponovo se pokazuje da ispitanici koji su kulturno otvoreniji i spremni na veću otvorenost prema ARH te oni koji ih ne doživljavaju kao prijetnju kulturi, identitetu ekonomiji i sigurnosti smatraju da bi zemljama primateljicama iz EU-a spomenuti proces mogao više koristiti nego štetiti. Nasuprot tome, oni ispitanici koji ARH više doživljavaju kao zdravstvenu i sigurnosnu prijetnju, oni koji ih više doživljavaju kao prikrivene ekonomske migrante, a ne prave izbjeglice te oni koji bi željeli da su bojom kože i etnički sličniji hrvatskom stanovništvu smatraju kako bi njihovim prihvatom zemlje primateljice imale više štete nego koristi. Gotovo identičnu situaciju nalazimo i u kontekstu stava ispitanika o štetama/koristima koje bi da Republika Hrvatska imala ako, sukladno kvotama EU-a, odobri azil i ostanak određenom broju MBI. Ipak, u ovom 
se slučaju povećava kako ukupni postotak objašnjene varijance kriterijske varijable tako i vrijednosti beta koeficijenta većine pojedinačnih prediktora. Jedini prediktor čija se vrijednost beta koeficijenta smanjuje u odnosu na prethodni slučaj stav je o (ne) vjerodostojnosti azilanata. Konačno, kada se promatra stav ispitanika o protivljenju/ podržavanju da RH, sukladno kvotama EU-a, odobri azil i ostanak određenom broju MBI pokazuje se da odabrani prediktori imaju još bolju prediktivnu moć nego u prethodnim slučajevima, kako na razini ukupno protumačene varijance tako i na razini vrijednosti beta koeficijenta pojedinačnih prediktora. Pokazuje se da ispitanici spremniji na veću socijalnu bliskost i kulturnu otvorenost te ispitanici koji ARH ne doživljavaju kao prijetnju kulturi, identitetu, ekonomiji i sigurnosti više podržavaju ideju da RH odobri azil određenom broju MBI. S druge stane, oni ispitanici koji smatraju da bi bilo poželjno kad bi potencijalni ARH bojom kože ili etničkim karakteristikama bili slični hrvatskom stanovništvu, oni koji ARH doživljavaju kao zdravstvenu i sigurnosnu prijetnju i oni koji smatraju da MBI nisu prave izbjeglice tendiraju protiviti se tomu da RH toj skupini migranata odobri azil.

\section{Rasprava i zaključak}

Studenti prava iz četiriju najvećih hrvatskih gradova ne razlikuju se po svojim stavovima prema migrantima i azilantima od ispitanika većine provedenih istraživanja u Hrvatskoj (usp. npr. Ajduković i sur., 2019.; Gregurović i sur., 2016.; Župarić-Iljić i Gregurović, 2013.). Iako se nazire tendencija negativnom stavu prema MBI, prosječni rezultati upućuju na neutralnost njihova stava. Jedino se u procjeni koristi i šteta od prihvaćanja migranata u zemljama EU-a studenti prava opredjeljuju za negativniju opciju, tj. procjenjuju da bi prihvaćanje migranata štetilo zemljama primateljicama iz Europske unije. Iako su neutralni u procjeni koliko bi bilo koristi/štete od prihvata MBI u Hrvatskoj, smatraju da zemlje EU-a od njih ne bi imale koristi te se na taj način priklanjaju stavu da se migranti (u odnosu na azilante/izbjeglice) prikazuju kao ekonomski oportunisti u potrazi za boljim životom, koji ne zaslužuju socijalna, ekonomska i politička prava (Holmes i Castaneda, 2016.), iako mnoge studije upućuju upravo na suprotne zaključke (Lalonde i Topel, 1997.; Jakobsen, 2002.; d'Albis i sur., 2018.).

Stavovi ispitanika prema ARH isto su većinom neutralni, iako je primjetan malen odmak prema pozitivnom, pri čemu se oni u prosjeku ne slažu s time da ARH predstavljaju zdravstvenu i sigurnosnu prijetnju te smatraju da željeni profil azilanta nužno ne treba biti „usklađen“ s etničkim odrednicama domicilnog stanovništva. Dempster i Hargrave (2017.:12) ističu da postoje indikacije da u većini zemalja najveći dio javnosti upravo zauzima tu neutralnu poziciju, tj. upada u tzv. „oprečnu“ ili „zabrinutu“ sredinu (engl. 'conflicted' or 'anxious' middle). Autorice naglašavaju da je ta sredina manje pod utjecajem ideologije u odnosu na one koji su uvjereno za i protiv imigracije te da ima više ambivalentne stavove prema izbjeglicama/azilantima i migrantima 
i procjene njihovih učinaka na društvo (Dempster i Hargrave, 2017.:12). Ta skupina ima tendenciju iskazivati kompleksne, pa i oprečne stavove, koji su također povezani s brojnim nekonzistencijama i kontradikcijama podataka postojećih istraživanja. Ipak, važno je istaknuti da su i takvi stavovi legitimni i validni jer naglašavaju kompleksnost sustava kreiranja stavova javnosti prema izbjeglicama/azilantima i migrantima.

Navedeno se može primijeniti na procjenu vjerodostojnosti ARH, gdje studenti prava $\mathrm{u}$ prosjeku azilante procjenjuju kao ekonomske migrante u potrazi za boljim životom. Verkuyten i sur. (2018.:914) ističu da je za procjenu vjerodostojnosti azilanata i podupiranje njihovih kulturnih prava važna procjena (ne)dobrovoljnosti migracije. ${ }^{19}$ Preciznije rečeno, ako su ispitanici procijenili da većina migranata nije imala drugog izbora nego napustiti svoju zemlju, tada su izražavali veću empatiju i jaču podršku i pomoć ostvarivanju kulturnih prava migrantima. Studenti prava u Hrvatskoj očito su skloniji smatrati da su ti migranti samostalno odgovorni za napuštanje svoje zemlje, te stoga prema njima iskazuju negativnije osjećaje.

Razlike prema sociodemografskim karakteristikama ispitanika donekle su sukladne nalazima mnogih postojećih istraživanja (Anderson i Ferguson, 2017.). Iako prema spolu nema većih razlika, muški su ispitanici ipak skloniji bliskijem kontaktu i kulturnoj otvorenosti prema ARH te u manjoj mjeri priželjkuju da su azilanti sličnih etničkih karakteristika kao hrvatsko stanovništvo od ispitanica. Takva je razlika suprotna očekivanom jer brojna istraživanja pokazuju da upravo muškarci imaju tendenciju izražavati negativnije stavove prema migrantima. Međutim, specifičnost ovoga istraživanja možda je u tome što je manji udio studenata uključen u istraživanje, te je rodna struktura značajno pomaknuta u korist studentica, što se onda može reflektirati i na dobivene rezultate, posebice kada se u obzir uzmu medijske prezentacije azilanata kao mladih i snažnih muškaraca koji dolaze sami te poneki izdvojeni slučajevi izvještavanja o napadima azilanata na mlade djevojke, što studenticama može u većoj mjeri nametnuti osjećaj ugroženosti i (sigurnosne) prijetnje.

Prema godini studija studenti se razlikuju samo u stavovima prema MBI. Pritom pozitivnije stavove prema njima iskazuju studenti prve godine studija te procjenjuju veće koristi od primitka azilanata u Hrvatskoj i u zemljama EU. Iako je relativno mala razlika u godinama, taj je nalaz konzistentan s drugim istraživanjima, koja upućuju na to da su mlađi ispitanici ujedno i otvoreniji prema kulturnim i etničkim različitostima te izražavaju pozitivnije stavove prema različitim skupinama doseljenika (v. npr. Pedersen, Griffiths i Watt, 2008.).

19 Na taj se način definira odgovornost migranta za napuštanje njegove zemlje porijekla i stav koji će se prema migrantu zauzeti, tj. percepcija da većina migranata ima mogućnost „osobnog izbora“ ili da „uopće nema izbora“" pruža okvir za donošenje prosudbe (Verkuyten i sur., 2018.). 
Ekonomski status ispitanika pokazao se značajnim jedino u vezi procjene koristi prihvaćanja MBI u zemljama EU-a, s čime se više slažu oni studenti srednjeg imovinskog statusa u odnosu na one nižeg i višeg imovinskog statusa. Navedeno upućuje na to da ispitanici ne vide u tim migrantima izravnu (ekonomsku?) prijetnju u vlastitoj zemlji, već prijetnju zemljama primateljicama u EU-u, pri čemu se ističu oni najvišeg i najnižeg socioekonomskog statusa, a što je moguće tumačiti u kontekstu procjene ekonomske prijetnje.

Gradovi u kojima se nalaze fakulteti iz kojih dolaze studenti mogu se promatrati kao predstavnici četiriju hrvatskih geografskih regija (usp. Ajduković i sur., 2019.). Pridajući tome i stupanj urbanizacije mjesta prebivališta, možemo razmotriti specifičnosti pojedine geografske okoline u izražavanju spomenutih stavova. Rezultati su pokazali da su studenti koji studiraju u Zagrebu i Rijeci skloniji odobravanju azila od studenata iz Splita i Osijeka. Također imaju pozitivnije osjećaje prema MBI i procjenjuju da će Hrvatska imati više koristi od odobravanja azila tim migrantima od studenta iz Splita. U stavovima prema ARH gotovo se jasno odvajaju Zagreb i Rijeka od Splita i Osijeka, pritom su prvi skloniji većoj bliskosti i kulturnoj otvorenosti te manjoj procjeni svih oblika prijetnje koju predstavljaju ARH od drugih. Studentima iz Splita važnije je da ARH po svojim karakteristikama budu sličniji domicilnom stanovništvu nego studentima iz Zagreba, a studenti iz Rijeke u većoj mjeri od osječkih studenata smatraju da je azilantima koji dolaze u RH uistinu potrebna međunarodna zaštita. Iz razmatranja na temelju veličine mjesta prebivališta proizlazi da su studenti iz Zagreba pozitivniji u svojim stavovima prema ARH od onih čije je prebivalište definirano kao mali i veliki grad: spremniji su na veću kulturnu otvorenost, u manjoj ih mjeri smatraju prijetnjom te više podržavaju odobravanje azila i ostanak MBI. Dobiveni su rezultati u skladu i s ranijim istraživanjima (Ajduković i sur., 2019.), koja pokazuju veći stupanj otvorenosti i prihvaćanja azilanata u središnjoj i sjeverozapadnoj te primorskoj Hrvatskoj u odnosu na slavonsku i dalmatinsku regiju. Pritom ističu da su veći gradovi spremniji na prihvat azilanata od manjih gradova. Ajduković i sur. (2019.:10) ističu $\mathrm{da}$, , [a]naliza regionalnih razlika pokazuje najmanje pozitivne stavove prema azilantima, najvišu percepciju i realistične i simbolične prijetnje, najnižu podršku pravima azilanata, najviša očekivanja negativnih promjena, te najmanju spremnost za pomoć kod sudionika u dalmatinskoj regiji. Nakon ove regije slijedi istočna Hrvatska, potom primorska i središnja Hrvatska, u kojima su ovi stavovi pozitivniji." Te se razlike mogu pripisati tome da su Zagreb i Rijeka nerijetko definirani kao izraženo multikulturni gradovi, koje karakterizira kulturna otvorenost i tolerantnost, za razliku od istočnih i dalmatinskih dijelova Hrvatske, koji su okarakterizirani kao izrazito tradicionalni i zatvoreniji u odnosu na različitost. Stoga su ti stavovi moguće zajednički i studentima prava u tim gradovima.

Kao i u mnogim drugim istraživanjima sociokulturne varijable koje predstavljaju ideološko pozicioniranje u političkom aspektu najviše su povezane s izraženim stavovima 
(usp. Anderson i Ferguson, 2017.; Semyonov i sur., 2006.; Pedersen i sur., 2005.). Općenito se pokazuje da studenti koji svoju političku orijentaciju opisuju kao lijevu ili lijevi centar izražavaju pozitivnije stavove prema MBI i ARH od studenata desne političke orijentacije. Takav se rezultat često interpretira u kontekstu teorije desničarske autoritarnosti (engl. right-wing authoritarianism, Altemeyer, 2006.), prema kojoj se izražavanje predrasuda i općenito negativnih stavova prema pripadnicima drugih skupina pripisuje motivacijskim interesima vezanima za grupnu koheziju, stabilnost i sigurnost. Religijska samoidentifikacija donekle prati rezultate političke orijentacije, no zabilježene su razlike rjeđe te upućuju na izdvajanje skupine nereligioznih studenata koji se ne protive religiji, a koji u prosjeku izražavaju pozitivnije osjećaje prema MBI i spremniji su na bliskiji odnos s ARH od studenata koji su uvjereni vjernici i religiozni. Nereligiozni studenti također u manjoj mjeri od religioznih smatraju azilante prijetnjom te manje od uvjerenih vjernika smatraju da bi ARH koji dolaze u Hrvatsku trebali biti određenog etničkog porijekla ili iz specifičnih zemalja. Na istom tragu Karyotis i Patrikios (2010.:44) na primjeru Grčke nalaze da je religioznost snažan prediktor antiimigrantskih stavova te da je izloženost sekuritizirajućem religijskom diskursu „zaštitila“ praktične vjernike od „ublažavajućeg učinka političke poruke“, a što implicira da su vjerske elite utjecale na proces sekuritizacije migracije, posebno u zemljama u kojima su nacionalni i vjerski identiteti usko isprepleteni (a što se može primijeniti i na Hrvatsku).

Analizirane kontekstualne varijable u maloj mjeri bilježe povezanost s izraženim stavovima. Dok u stavovima prema MBI nisu zabilježene značajne razlike s obzirom na vlastito ili obiteljsko iskustvo raseljenosti, kontakt $s$ azilantima i prijateljstvo sa strancima, razlike u stavovima prema ARH povezane su najviše s kontaktom s njima. $\mathrm{Na}$ bliskiji odnos uz veću kulturnu otvorenost prema ARH te manju procjenu zdravstvene i sigurnosne prijetnje spremniji su oni studenti koji su upoznali tražitelje azila ili azilante. Studenti koji imaju prijatelje strance također su otvoreniji prema azilantima i ne očekuju da po etničkim karakteristikama budu slični domicilnom stanovništvu. Navedeno se može povezati s hipotezom kontakta (Allport, 1954.), prema kojoj osobe koje su ostvarile kontakt sa „strancem“ većinom imaju pozitivnije stavove i manje predrasuda prema toj skupini. Prijateljstvo između pripadnika različitih (etničkih) skupina, pa čak i neizravni kontakt (npr. putem medija) mogu smanjiti predrasude i potaknuti „proimigrantske“ stavove (Pettigrew i sur., 2011.). Također, multikulturna okolina koju karakteriziraju različiti međuetnički odnosi pridonosi kreiranju pozitivnijih stavova (Berg, 2009.).

Nasuprot očekivanom, studenti s osobnim/obiteljskim iskustvom raseljenosti u manjoj mjeri smatraju da su azilanti koji dolaze u Hrvatsku uistinu izbjeglice kojima je potrebna međunarodna zaštita i više ih identificiraju kao ekonomske migrante u potrazi za boljim životom. Iako je u ovome i prijašnjim istraživanjima očekivan pozitivan odnos upravo zbog pojačane osjetljivosti i empatije izazvane osobnim iskustvom ( $\check{Z}_{\text {u- }}$ 
parić-Iljić i Gregurović, 2013.; Gregurović i sur., 2016.), dobiveni rezultati pokazuju suprotno, što može upućivati na mogućnost da zbog velike diverzificiranosti tražitelja azila i azilanata u Hrvatskoj (različite etničke strukture, zemlje porijekla i razlozi za napuštanjem matične države) studenti nalaze teškim poistovjetiti svoje/obiteljsko iskustvo raseljenosti koje je bilo potaknuto isključivo ratnim razaranjima.

Naposljetku, utvrđena je očekivana značajna povezanost i učinak stavova prema ARH na općenite stavove prema MBI, a pritom najveći učinak ima procjena bliskosti i tendencija kulturnoj otvorenosti te manja percepcija ARH kao prijetnje. Stavovi prema objema skupinama migranata usko su povezani te se mogu razmatrati u okviru općenite dimenzije anti/pro-migrantskih stavova, na koje značajan učinak ima upravo procjena stupnja stvarne ili simbolične prijetnje koju pojedina skupina predstavlja bez obzira na razloge njihove migracije. Kako Dempster i Hargrave (2017.:15) upućuju, „narativ prijetnje“ često u mnogim okolnostima koriste politički predstavnici krajnje desnice kako bi opisali azilante i migrante kao izazov i prijetnju vrijednostima i kulturi, kao izvor terorizma i kriminala te kao prijetnju životnim standardima, poslovima i javnim uslugama. Ipak, istovremeno, „većina ljudi ima kompleksne stavove prema migrantima i azilantima koji se formiraju kroz složen splet briga, u procesu koji se podjednako oslanja na emocije i individualne vrijednosti kao i na racionalnu analizu dokaza“ (Dempster i Hargrave, 2017.:15), a što je od posebnog značaja za studente prava i njihov budući poziv.

Općenito gledano, stavovi studenata prava, koji se ne razlikuju u velikoj mjeri od stavova opće populacije, te tendencija negativnijim stavovima s odmakom u studiju (stariji studenti s negativnijim stavovima) upućuju na moguće učinke samog studija prava. Iako bi bilo za očekivati da će studenti viših godina biti informiraniji i senzibiliziraniji za ovu problematiku, čini se da to nije tako te da se studenti Integriranog studija prava ne susreću u velikoj mjeri s analiziranom problematikom. Predmet „Migracije, azil i stranci“ opcionalan je tek za studente Studijskog centra za javnu upravu i javne financije (pri Pravnom fakultetu Sveučilišta u Zagrebu), a ta skupina studenata nije bila uključena u ovo istraživanje. Preporuka je učiniti problematiku migracija i azila dostupnom široj skupini studenata prava te ih uključiti u različite oblike praktičnog rada i izravnog kontakta s analiziranim skupinama budući da se na taj način omogućuje adekvatna informiranost vezana uz struku, veća nepristranost i osjetljivost (v. npr. Gilbert, 2019.). U suprotnom, ako pravna socijalizacija i dalje znatno ostane pod dojmom općih stavova, uistinu postoji mogućnost da će se ti stavovi otkloniti u negativnu stranu, pa će se ranjive skupine migranata doslovno početi doživljavati kao neprijatelji i među onim stručnjacima koji bi im trebali biti od pomoći.

Ograničenja ove studije vežu se uz određenu prigodnost uzorka budući da se anketiralo studente prve i četvrte godine studija u okviru grupne nastave te se nije moglo izravno voditi računa o strukturi studenata prisutnih na nastavi. Uzorak stoga ograničava 
izravnu generalizaciju dobivenih rezultata na sve studente prava u četirima hrvatskim gradovima. Nadalje, činjenica da je primijenjena metoda ankete govori da je istraživanje kros-sekcijskog tipa, odnosno da odražava stavove prikupljene u jednom trenutku i upućuje na to da su stavovi možda bili pod utjecajem određenih kontekstualnih čimbenika. U budućim bi se analizama trebalo usmjeriti na ispitivanje mogućih učinaka na kreiranje ovih stavova kod studenata prava te ispitati do koje su oni mjere bili pod utjecajem političkih i medijskih javnih diskursa.

\section{Literatura}

1. Ajduković, D.; Čorkalo Biruški, D.; Gregurović, M.; Matić Bojić, J.; ŽuparićIljić, D. (2019). Izazovi integracije izbjeglica u hrvatsko drustvo: stavovi gradana i pripremljenost lokalnih zajednica. Zagreb: Vlada Republike Hrvatske Ured za ljudska prava i prava nacionalnih manjina.

2. Allport, G. W. (1954). The Nature of Prejudice. Cambridge: Addison-Wesley Publishing.

3. Altemeyer, B. (2006). The Authoritarians. Winnipeg: University of Manitoba.

4. Anderson, J. and Ferguson, R. (2017). Demographic and ideological correlates of negative attitudes towards asylum seekers: A meta-analytic review. Australian Journal of Psychology, 70 (1): 18-29.

5. Benčić, S.; Bužinkić, E.; Miletić, G.; Parić, A.; Župarić-Iljić, D. (2005). Azil u Hrvatskoj-Analiza rezultata istraživanja. Zagreb: Centar za mirovne studije.

6. Berg, J. A. (2009). Core networks and whites' attitudes toward immigrants and immigration policy. Public Opinion Quarterly, 73 (1): 7-31.

7. Cowling, M. M.; Anderson, J. R. and Ferguson, R. (2019). Prejudice-relevant Correlates of Attitudes towards Refugees: A Meta-analysis. Journal of Refugee Studies, 32 (3): 502-524.

8. C Čačić-Kumpes, J.; Gregurović, S. i Kumpes, J. (2012). Migracija, integracija i stavovi prema imigrantima u Hrvatskoj. Revija za sociologiju, 42 (3): 305-336.

9. d'Albis, H.; Boubtane, E. and Coulibaly, D. (2018). Macroeconomic evidence suggests that asylum seekers are not a "burden" for Western European countries. Science Advances, 4 (6): eaaq0883.

10. Davidov, E. and Semyonov, M. (2017). Attitudes toward immigrants in European societies. International Journal of Comparative Sociology, 58 (5): 359-366.

11. Dempster, H. and Hargrave, K. (2017). Understanding public attitudes towards refugees and migrants, Chatham House and ODI's Forum on Refugee and Migration Policy initiative, Working paper 512.

12. Franc, R.; Šakić, V. i Kaliterna-Lipovčan, Lj. (2010). Percipirane posljedice doseljavanja i stav prema doseljavanju. Društvena istraživanja, 19 (3): 421-440.

13. Georgiou, M. i Zaborowski, R. (2017). Media Coverage of the Refugee Crisis: A Cross-European Perspective. Council of Europe Report, April 2017. https:// rm.coe.int/1680706b00. (Pregledano 19. srpnja 2020.) 
14. Gilbert, L. (2019). A justice school: Teaching forced migration through experiential learning. Intercultural Human Rights Law Review, 14: 129-166.

15. Gill, N. (2018). The suppression of welcome. Fennia, 196 (1): 88-98.

16. Gregurović, M.; Kuti, S. and Župarić-Iljić, D. (2016). Attitudes towards immigrant workers and asylum seekers in Eastern Croatia: dimensions, determinants and differences. Migracijske i etničke teme, 32 (1): 91-122.

17. Gregurović, M.; Radeljak Kaufmann, P.; Župarić-Iljić, D.; Dujmović, M. (2019). Are attitudes determined by location? Differences in perceptions of asylum seekers between residents of two Zagreb neighbourhoods. Geoforum, 104 (2019): 244-258.

18. Hainmueller, J. and Hiscox, M. J. (2007). Educated preferences: explaining attitudes toward immigration in Europe. International Organization, 61 (2): 399-442.

19. Holmes, S. M. and Castaneda, H. (2016). Representing the "European refugee crisis" in Germany and beyond: deservingness and difference, life and death. American Ethnologist, 43 (1): 12-24.

20. Huysmans, J. (2006). The politics of insecurity: Fear, migration and asylum in the $E U$. London - New York: Routledge.

21. Jacobsen, K. (2002). Can refugees benet the state? Refugee resources and African statebuilding. The Journal of Modern African Studies, 40: 577-596.

22. Karyotis, G. and Patrikios, S. (2010). Religion, securitization and anti-immigration attitudes: the case of Greece. Journal of Peace Research, 47 (1): 43-57.

23. Lalić Novak, G. (2010). Razvoj sustava azila u Hrvatskoj. Zagreb: Društveno veleučilište u Zagrebu.

24. Lalić Novak, G. (2016). Azil: pravni i institucionalni aspekti. Zagreb: Pravni fakultet Sveučilišta u Zagrebu, Studijski centar za javnu upravu i javne financije.

25. Lalić Novak, G. and Giljević, T. (2018). Integration of 'new' refugees in the non- immigrant countries along the Balkan route of migration - overview of legal framework and practices, in: Jílek, D. and Pořízek, P. (Eds.). Ročenka uprchlického a cizineckého práva 2017. Brno: Kancelář veřejného ochránce práv.

26. Lalonde, R. J. and Topel, R. H. (1997). Economic Impact Of International Migration And The Economic Performance Of Migrants, in: Rosenzweig, M. R. and Stark, O. (Eds.). Handbook of Population and Family Economics. Amsterdam: Elsevier.

27. Loescher, G. (1989). The European Community and Refugees. International Affairs, 65 (4): 617-636.

28. Loschmann, C.; Bilgili, Ö. and Siegel, M. (2019). Considering the benefits of hosting refugees: evidence of refugee camps influencing local labour market activity and economic welfare in Rwanda. IZA Journal of Development and Migration, 9 (5).

29. Lubbers, M.; Coenders, M. and Scheepers, P. (2006). Objections to asylum seeker centres: individual and contextual determinants of resistance to small and large centres in the Netherlands. European Sociological Review, 22 (3): 243-257. 
30. Lynn, N. and Lea, S. (2003). A Phantom Menace and the New Apartheid: Social Construction of Asylum Seekers in the UK. Discourse Society, 14: 425-452.

31. Marinović Jerolimov, D. (2005). Društvene i religijske promjene u Hrvatskoj: teorijsko-hipotetski okvir istraživanja. Sociologija sela, 43 (2): 289-302

32. McConnachie, K. (2014). Governing Refugees: Justice, Order and Legal Pluralism. Oxon - New York: Routledge.

33. McKay, F. H.; Thomas, S. L. and Kneebone, S. (2012). 'It Would be Okay If They Came through the Proper Channels' community perceptions and attitudes toward Asylum Seekers in Australia. Journal of Refugee Studies, 25 (1): 113-133.

34. Medlobi, M. i Čepo, D. (2018). Stavovi korisnika društvenih mreža o izbjeglicama i tražiteljima azila: post festum tzv. izbjegličke krize. Političke perspektive, 8 (1-2): 41-69.

35. Mesić, M. i Bagić, D. (2011). Stavovi hrvatskih građana prema kulturnim različitostima. Migracijske i etničke teme, 27 (1): 7-38.

36. Mrakovčić, M. i Vuković, D. (2019). „Unutarnja“ kriza pravosuđa? Stavovi pravničkih profesija o pravosuđu u Hrvatskoj i Srbiji. Politička misao, 56 (1): 75-105.

37. O'Nions, H. (2014). Asylum - A Right Denied, A Critical Analysis of European Asylum Policy. Farnham - Burlington: Ashgate.

38. Peace, F. (2019). Turning the Tide: How Immigration is Helping Reverse Depopulation and Decline. A Global Future Report. London. https://ourglobalfuture. com/reports/turning-the-tide-how-immigration-is-helping-reverse-depopulation-and-decline/. (Pregledano 29. studenog 2020.)

39. Pedersen, A.; Attwell, J. and Heveli, D. (2005). Prediction of negative attitudes toward Australian asylum seekers: false beliefs, nationalism, and self-esteem. Australian Journal of Psychology, 57 (3): 148-160.

40. Pedersen, A.; Griffiths, B. and Watt, S. E. (2008). Attitudes toward Out-groups and the perception of consensus: All feet do not wear one shoe. Journal of Community \& Applied Social Psychology, 18 (6): 543-557.

41. Pereira, C.; Vala, J. and Costa-Lopes, R. (2009). From prejudice to discrimination: The legitimizing role of perceived threat in discrimination against immigrants. European Journal of Social Psychology, 40 (7): 1231-1250.

42. Petrović, D. i Pozniak, R. (2014). Tražitelji azila kao prijetnja. Studia ethnologica Croatica, 26 (1): 47-72.

43. Petrović, N. (2006). Centri za tražitelje azila kao rizični objekti: slučaj Stubičke Slatine. Diplomski rad, Filozofski fakultet Sveučilište u Zagrebu.

44. Pettigrew, T. F. and Tropp, L. R. (2005). Allport's intergroup contact hypothesis: its history and influence, in: Dovidio, J. F.; Glick, P. and Rudman, L. A. (Eds.). On the Nature of Prejudice: Fifty Years after Allport. Malden - Oxford - Carlton: Blackwell Publishing.

45. Pettigrew, T. F.; Tropp, L. R.; Wagner, U.; Christ, O. (2011). Recent advances in intergroup contact theory. International Journal of Intercultural Relations, 35 (3): $271-280$. 
46. Rustenbach, E. (2010). Sources of Negative Attitudes toward Immigrants in Europe: A Multi-Level Analysis. International Migration Review, 44 (1): 53-77.

47. Schultz, U. and Shaw, G. (2003). Women in the World's Legal Professions. Oxford: Hart Publishing.

48. Semyonov, M.; Raijman, R. and Gorodzeisky, A. (2006). The rise of antiforeigner sentiment in European societies, 1988-2000. American Sociological Review, 71 (3): 426-449.

49. Sides, J. and Citrin, J. (2007). European opinion about immigration: the role of identities, interests and information. British Journal of Political Science, 37 (3): 477-504.

50. Stephan, W. G.; Ybarra, O. and Bachman, G. (1999). Prejudice toward immigrants. Journal of Applied Social Psychology, 29 (11): 2221-2237.

51. Šram, Z., (2010). Etnocentrizam, percepcija prijetnje i hrvatski nacionalni identitet. Migracijske i etničke teme, 26 (2): 113-142

52. Tamanaha, B. Z. (2004). On the Rule of Law: History, Politics, Theory. Cambridge: Cambridge University Press.

53. Verkuyten, M.; Mepham, K. and Kros, M. (2018). Public attitudes towards support for migrants: the importance of perceived voluntary and involuntary migration, Ethnic and Racial Studies, 41 (5): 901-918.

54. Worthington, R. L. and Whittaker, T. A. (2006). Scale Development Research: A Content Analysis and Recommendations for Best Practices. The Counseling Psychologist, 34 (6): 806-838.

55. Wright, C. F.; Clibborn, S.; Piper, N.; Cini, N. (2016). Analysis: Economic Migration and Australia in the 21st Century. Sidney: Lowy Institute. https://www. lowyinstitute.org/publications/economic-migration-and-australia-21st-century. (Pregledano 29. studenog 2020.)

56. Yong, A. G. and Pearce, S. (2013). A beginner's guide to factor analysis: Focusing on exploratory factor analysis. Tutorials in Quantitative Methods for Psychology, 9 (2): 79-94.

57. Zakon o međunarodnoj i privremenoj zaštiti, Narodne novine 70 od 2015 i 127 od 2017.

58. Zavratnik, S. (2012). Images of Immigrants in Slovenia: Insights from Public Opinion. Ethnicity Studies / Etniskumo Studijos, 1-2: 204-223.

59. Zetter, R. (2012). Are refugees an economic burden or benefit?. Forced Migration Review, 41:50-52.

60. Župarić-Iljić, D. (2013). Percepcija tražitelja azila u javnosti i medijski prikazi problematike azila u Hrvatskoj, u: Župarić-Iljić, D. (Ur.). Prvih deset godina razvoja sustava azila u Hrvatskoj (s osvrtom na sustave azila u regiji). Zagreb: Institut za migracije i narodnosti - Centar za mirovne studije - Kuća ljudskih prava.

61. Župarić-Iljić, D. i Gregurović, M. (2013). Stavovi studenata prema tražiteljima azila u Republici Hrvatskoj. Društvena istraživanja, 22 (1): 41-62. 
Prilog 1 - Deskriptivni pokazatelji čestica skale stavova prema azilantima u RH i njihova distribucija i zasićenja na faktorima

\begin{tabular}{|c|c|c|c|c|c|c|c|c|c|}
\hline & 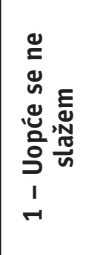 & 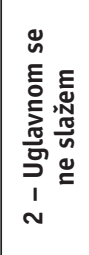 & 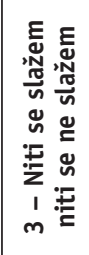 & 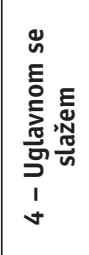 & 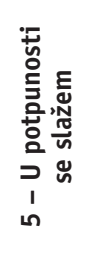 & $\mathbf{z}$ & $\Sigma$ & ㅇ & 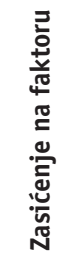 \\
\hline \multicolumn{10}{|c|}{ F1 Bliskost i kulturna otvorenost prema azilantima, sloboda azilanata (Cronbachov $\alpha$ kompozitne skale $=, 852$ ) } \\
\hline $\begin{array}{l}\text { 1.11. Ako bi moje dijete, brat } \\
\text { ili sestra imalo priliku u školi } \\
\text { dopunski učiti jezik kojim govori } \\
\text { dijete azilant, podržao/la bih to. }\end{array}$ & $11,6 \%$ & $10,7 \%$ & $25,5 \%$ & $28,8 \%$ & $23,3 \%$ & 670 & 3,41 & 1,274 & ,683 \\
\hline $\begin{array}{l}\text { 1.4. Azilanti mogu kulturno } \\
\text { obogatiti hrvatsko društvo. }\end{array}$ & $17,2 \%$ & $18,4 \%$ & $36,7 \%$ & $21,0 \%$ & $6,6 \%$ & 662 & 2,81 & 1,147 & 677 \\
\hline $\begin{array}{l}\text { 1.13. Pomogao/la bih azilantu ako } \\
\text { bih bio/la u mogućnosti. }\end{array}$ & $3,3 \%$ & $5,2 \%$ & $20,8 \%$ & $42,0 \%$ & $28,6 \%$ & 667 & 3,87 & 0,994 & ,623 \\
\hline $\begin{array}{l}\text { 1.27. Azilanti mogu utjecati na } \\
\text { poboljšanje demografske slike } \\
\text { onih područja Hrvatske koja gube } \\
\text { stanovništvo. }\end{array}$ & $15,9 \%$ & $14,1 \%$ & $35,5 \%$ & $25,6 \%$ & $8,8 \%$ & 667 & 2,97 & 1,178 & ,614 \\
\hline $\begin{array}{l}\text { 1.5. Ne bih imao/la ništa protiv } \\
\text { pozvanja azilanta na druženje } \mathrm{u} \\
\text { svoj dom. }\end{array}$ & $26,3 \%$ & $19,5 \%$ & $24,5 \%$ & $18,8 \%$ & $26,3 \%$ & 666 & 2,69 & 1,333 & ,595 \\
\hline $\begin{array}{l}\text { 1.21. Voljan/voljna sam popričati } \\
\text { s azilantom koji bi me zaustavio } \\
\text { na ulici. }\end{array}$ & $7,1 \%$ & $12,0 \%$ & $23,6 \%$ & $34,4 \%$ & $22,9 \%$ & 665 & 3,54 & 1,171 & ,538 \\
\hline $\begin{array}{l}\text { 1.28. Azilantima treba biti } \\
\text { omogućena sloboda kretanja u } \\
\text { Republici Hrvatskoj. }\end{array}$ & $8,6 \%$ & $15,4 \%$ & $31,9 \%$ & $27,3 \%$ & $16,8 \%$ & 671 & 3,28 & 1,169 &, 536 \\
\hline $\begin{array}{l}\text { 1.17. Kultura azilanata ne treba se } \\
\text { miješati s hrvatskom kulturom. }\end{array}$ & $12,4 \%$ & $15,1 \%$ & $27,6 \%$ & $23,8 \%$ & $21,0 \%$ & 667 & 3,26 & 1,290 &,- 486 \\
\hline $\begin{array}{l}\text { 1.22. Ako žele, azilanti trebaju } \\
\text { moći slobodno izražavati svoje } \\
\text { vlastite običaje i tradiciju. }\end{array}$ & $7,6 \%$ & $12,0 \%$ & $23,9 \%$ & $34,2 \%$ & $22,3 \%$ & 669 & 3,52 & 1,181 & ,419 \\
\hline \multicolumn{10}{|c|}{ F2 Azilanti kao zdravstvena i sigurnosna prijetnja (Cronbachov $\alpha$ kompozitne skale $=, 800$ ) } \\
\hline $\begin{array}{l}\text { 1.3. Azilanti predstavljaju } \\
\text { zdravstvenu prijetnju u zajednici. }\end{array}$ & $16,5 \%$ & $30,6 \%$ & $31,5 \%$ & $16,8 \%$ & $4,6 \%$ & 667 & 2,63 & 1,087 &, 785 \\
\hline $\begin{array}{l}\text { 1.26. Azilanti su prenositelji } \\
\text { opasnih bolesti. }\end{array}$ & $25,0 \%$ & $28,0 \%$ & $34,9 \%$ & $8,2 \%$ & $3,9 \%$ & 668 & 2,38 & 1,066 & ,720 \\
\hline $\begin{array}{l}\text { 1.2. Azilanti su ustvari prikriveni } \\
\text { teroristi. }\end{array}$ & $28,0 \%$ & $32,9 \%$ & $27,3 \%$ & $7,7 \%$ & $4,0 \%$ & 671 & 2,27 & 1,075 & ,636 \\
\hline 1.19. Azilanti su ustvari kriminalci. & $33,0 \%$ & $29,1 \%$ & $30,4 \%$ & $4,5 \%$ & $3,0 \%$ & 664 & 2,16 & 1,031 & ,489 \\
\hline
\end{tabular}




\begin{tabular}{|c|c|c|c|c|c|c|c|c|c|}
\hline & 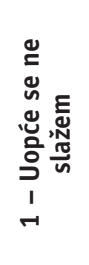 & 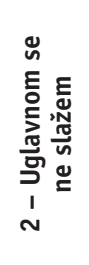 & 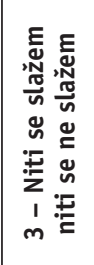 & 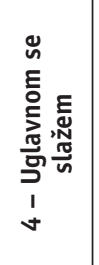 & 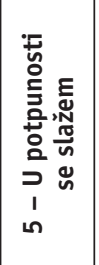 & $z$ & $\Sigma$ & 오 & 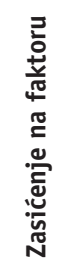 \\
\hline \multicolumn{10}{|c|}{$\begin{array}{l}\text { F3 Azilanti ne predstavljaju prijetnju kulturi, identitetu, ekonomiji i sigurnosti (Cronbachov } \alpha \\
\text { kompozitne skale }=, 766)\end{array}$} \\
\hline $\begin{array}{l}\text { 1.16. Azilanti ne predstavljaju } \\
\text { prijetnju za nacionalno jedinstvo } \\
\text { Hrvatske. }\end{array}$ & $10,8 \%$ & $16,7 \%$ & $27,4 \%$ & $25,6 \%$ & $19,5 \%$ & 665 & 3,26 & 1,253 & ,687 \\
\hline $\begin{array}{l}\text { 1.25. Azilanti ne ugrožavaju } \\
\text { stabilnost političkog poretka } \\
\text { Hrvatske. }\end{array}$ & $8,2 \%$ & $20,0 \%$ & $34,3 \%$ & $22,7 \%$ & $14,8 \%$ & 661 & 3,16 & 1,150 &, 655 \\
\hline $\begin{array}{l}\text { 1.8. Azilanti svojom kulturom ne } \\
\text { predstavljaju prijetnju hrvatskoj } \\
\text { kulturi. }\end{array}$ & $12,1 \%$ & $17,1 \%$ & $25,1 \%$ & $26,6 \%$ & $19,2 \%$ & 662 & 3,24 & 1,278 &, 569 \\
\hline $\begin{array}{l}\text { 1.18. Azilanti ne predstavljaju } \\
\text { opterećenje za porezne obveznike. }\end{array}$ & $22,9 \%$ & $29,1 \%$ & $33,6 \%$ & $10,8 \%$ & $3,6 \%$ & 664 & 2,43 & 1,067 &, 564 \\
\hline $\begin{array}{l}\text { 1.7. Azilanti ne predstavljaju } \\
\text { sigurnosni problem u zajednici gdje } \\
\text { su smješteni. }\end{array}$ & $14,5 \%$ & $28,2 \%$ & $32,9 \%$ & $20,4 \%$ & $4,1 \%$ & 663 & 2,71 & 1,071 &, 542 \\
\hline $\begin{array}{l}\text { 1.1. Azilanti nisu teret za } \\
\text { ekonomski razvoj naše zemlje. }\end{array}$ & $17,6 \%$ & $28,1 \%$ & $30,2 \%$ & $20,0 \%$ & $4,0 \%$ & 669 & 2,65 & 1,107 &, 453 \\
\hline \multicolumn{10}{|c|}{ F4 Željeni profil azilanata (Cronbachov $\alpha$ kompozitne skale $=, 651$ ) } \\
\hline $\begin{array}{l}\text { 1.20. Volio/voljela bih da su azilanti } \\
\text { u RH po boji kože slični hrvatskom } \\
\text { stanovništvu. }\end{array}$ & $51,3 \%$ & $16,8 \%$ & $23,7 \%$ & $4,3 \%$ & $3,9 \%$ & 668 & 1,93 & 1,127 & ,748 \\
\hline $\begin{array}{l}\text { 1.12. Volio/voljela bih da su azilanti } \\
\text { po svojoj etničkoj pripadnosti slični } \\
\text { hrvatskom stanovništvu. }\end{array}$ & $18,8 \%$ & $15,3 \%$ & $38,0 \%$ & $18,3 \%$ & $9,5 \%$ & 665 & 2,84 & 1,202 & ,668 \\
\hline $\begin{array}{l}\text { 1.15. Volio/voljela bih da azilanti } \\
\text { dolaze isključivo iz razvijenih } \\
\text { zemalja. }\end{array}$ & $24,2 \%$ & $15,7 \%$ & $38,4 \%$ & $14,6 \%$ & $7,0 \%$ & 669 & 2,65 & 1,196 &, 526 \\
\hline \multicolumn{10}{|c|}{ F5 Vjerodostojnost azilanata (Cronbachov $\alpha$ kompozitne skale $=, 520$ ) } \\
\hline $\begin{array}{l}\text { 1.9. Azilanti su ustvari prikriveni } \\
\text { ekonomski migranti u potrazi za } \\
\text { boljim životom. }\end{array}$ & $5,9 \%$ & $11,6 \%$ & $31,2 \%$ & $37,0 \%$ & $14,3 \%$ & 663 & 3,42 & 1,057 &, 755 \\
\hline $\begin{array}{l}\text { 1.29. Ljudi koji trenutno dolaze } \\
\text { u Europu nisu prave izbjeglice, } \\
\text { jer dolaze u potrazi za zaradom i } \\
\text { boljim životom. }\end{array}$ & $7,2 \%$ & $14,8 \%$ & $37,1 \%$ & $26,5 \%$ & $14,5 \%$ & 671 & 3,26 & 1,100 &, 725 \\
\hline \multicolumn{10}{|c|}{$\begin{array}{l}\text { Extraction Method: Principal Component Analysis. } \\
\text { Rotation Method: Varimax with Kaiser Normalization. } \\
\text { Kaiser-Meyer-Olkin Measure of Sampling Adequacy = } 0,926 \\
\text { Bartlett's Test of Sphericity = } 4562,059\end{array}$} \\
\hline
\end{tabular}




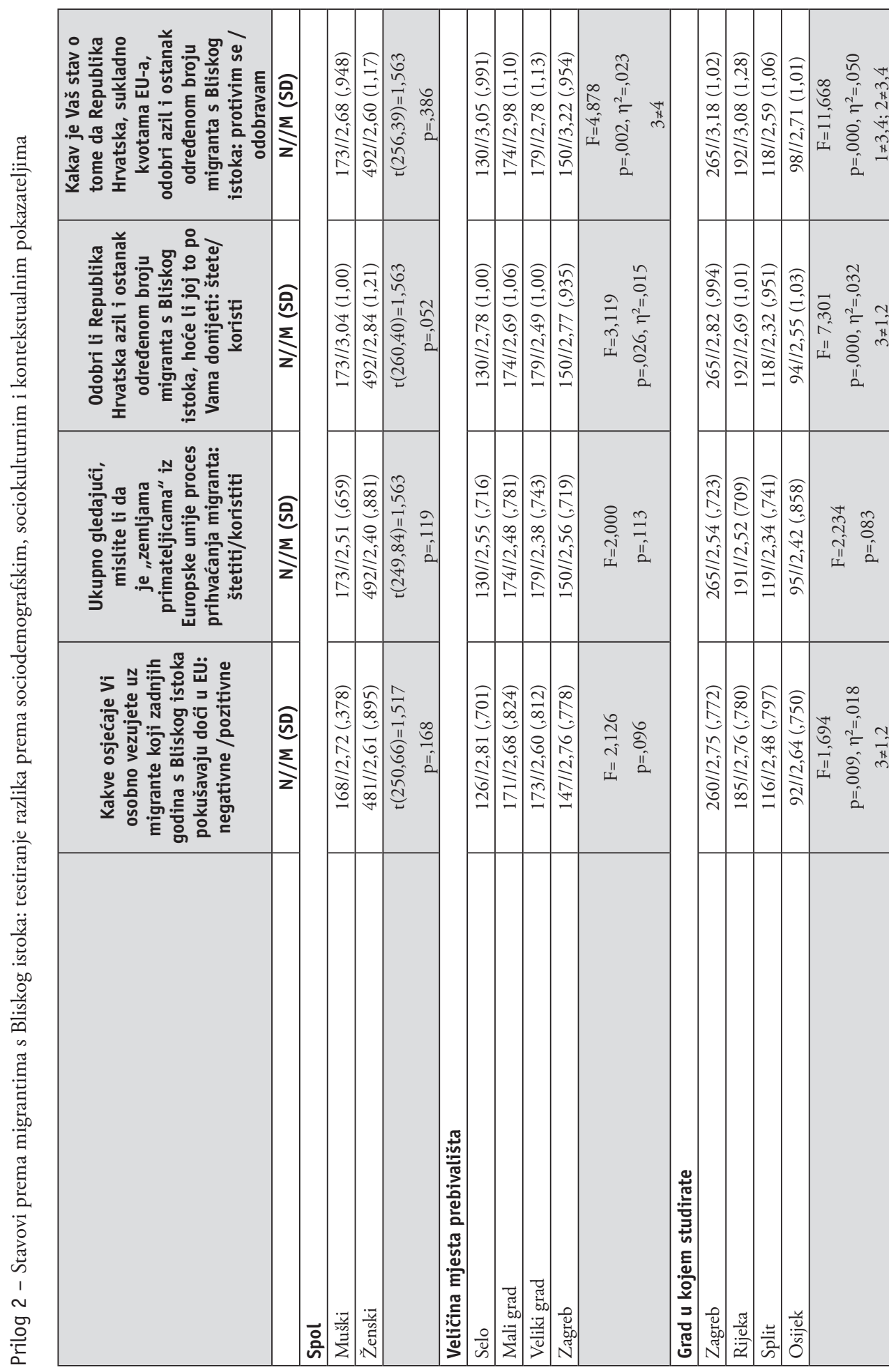




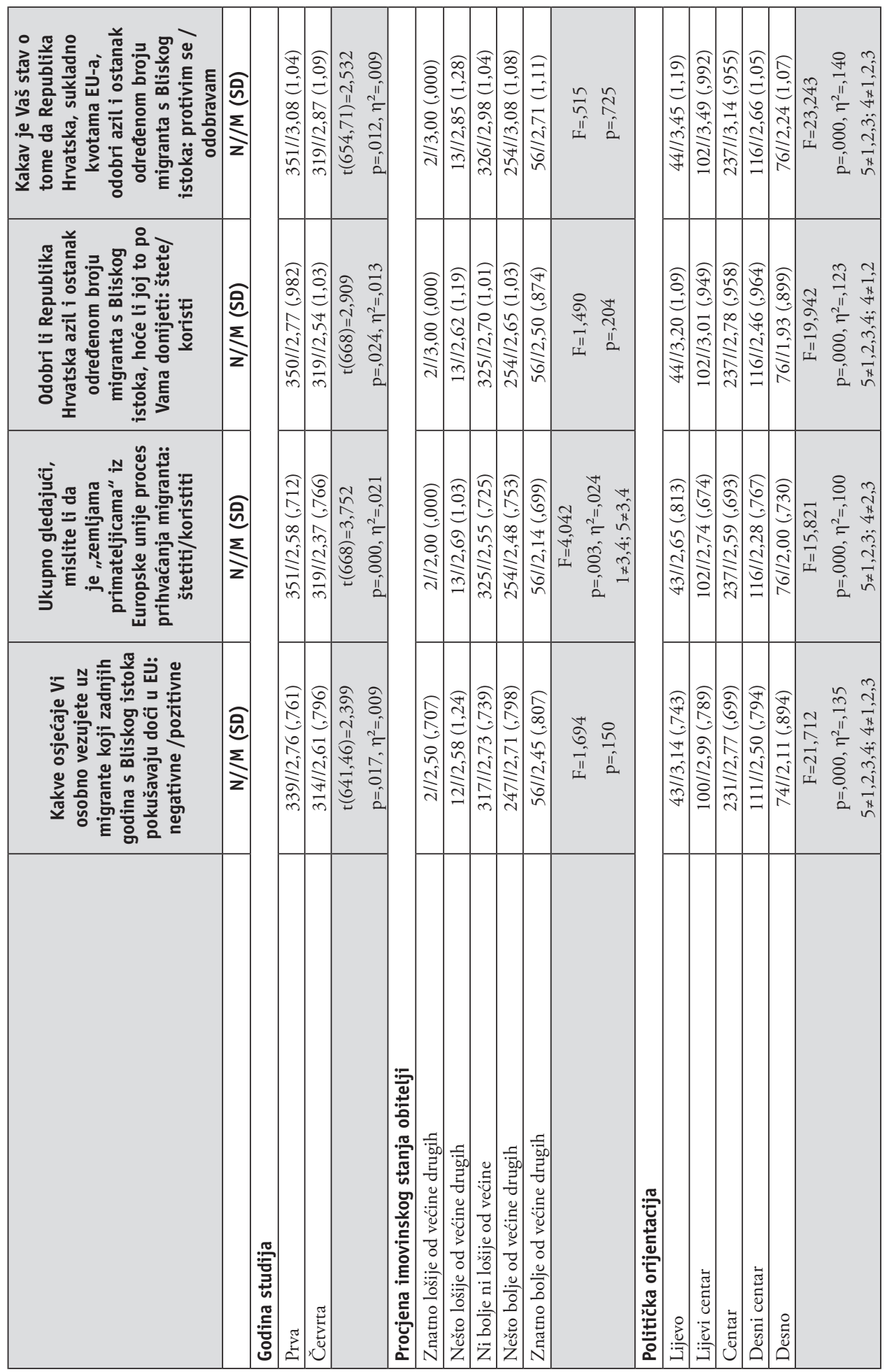




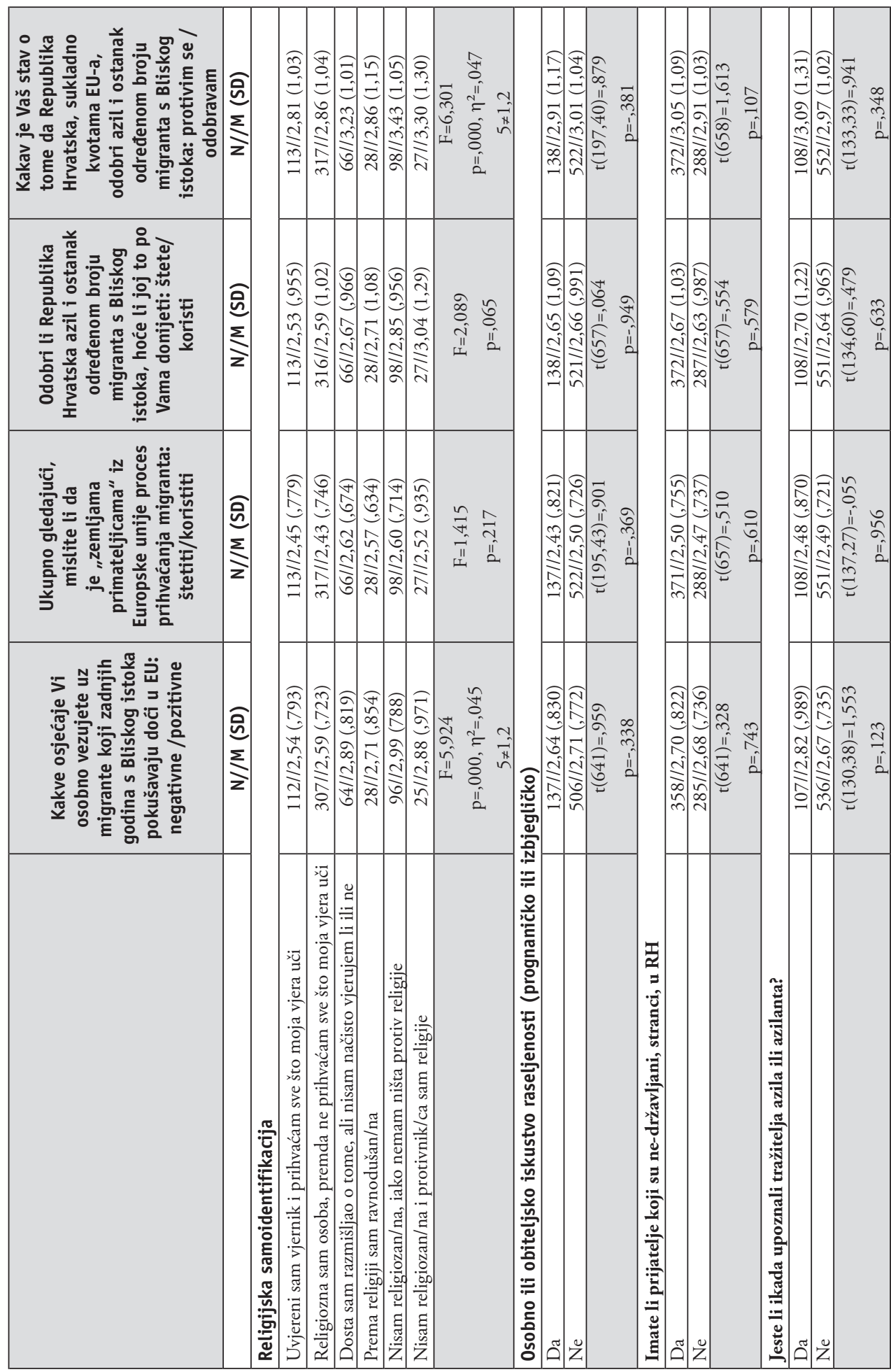



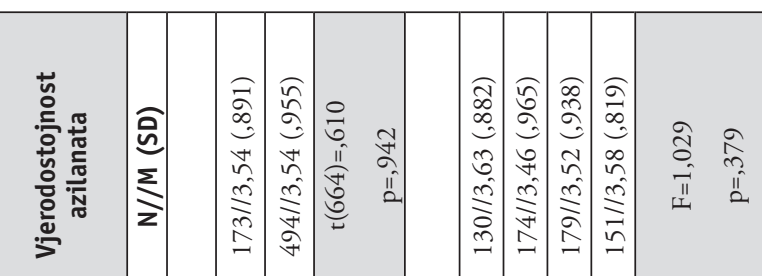

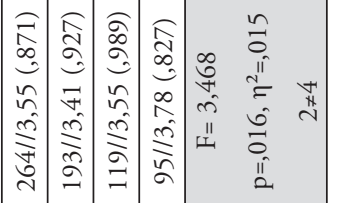
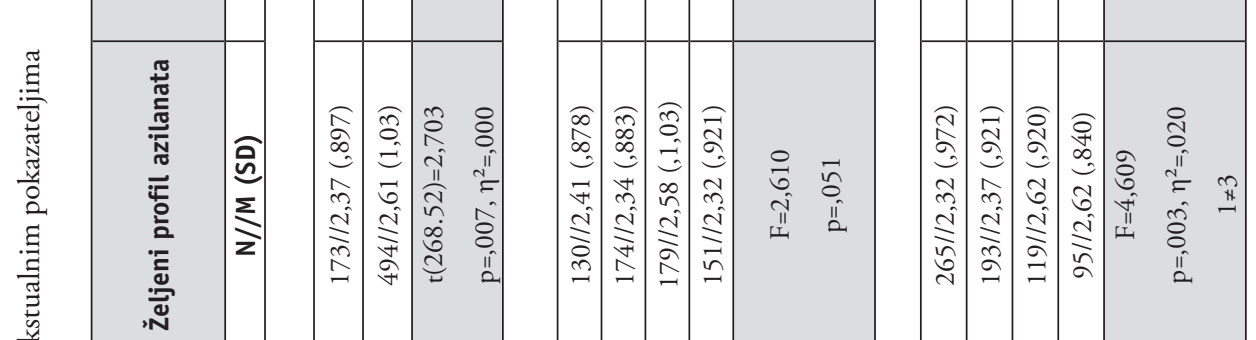

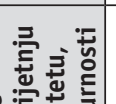

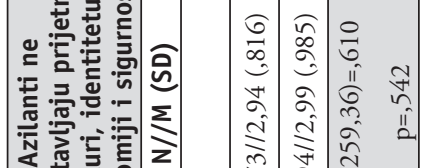

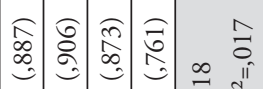

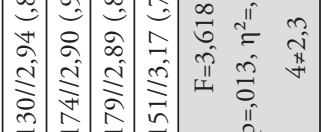

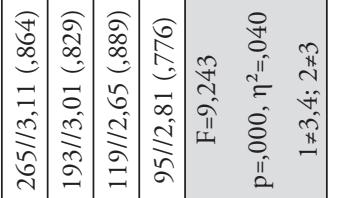

咅
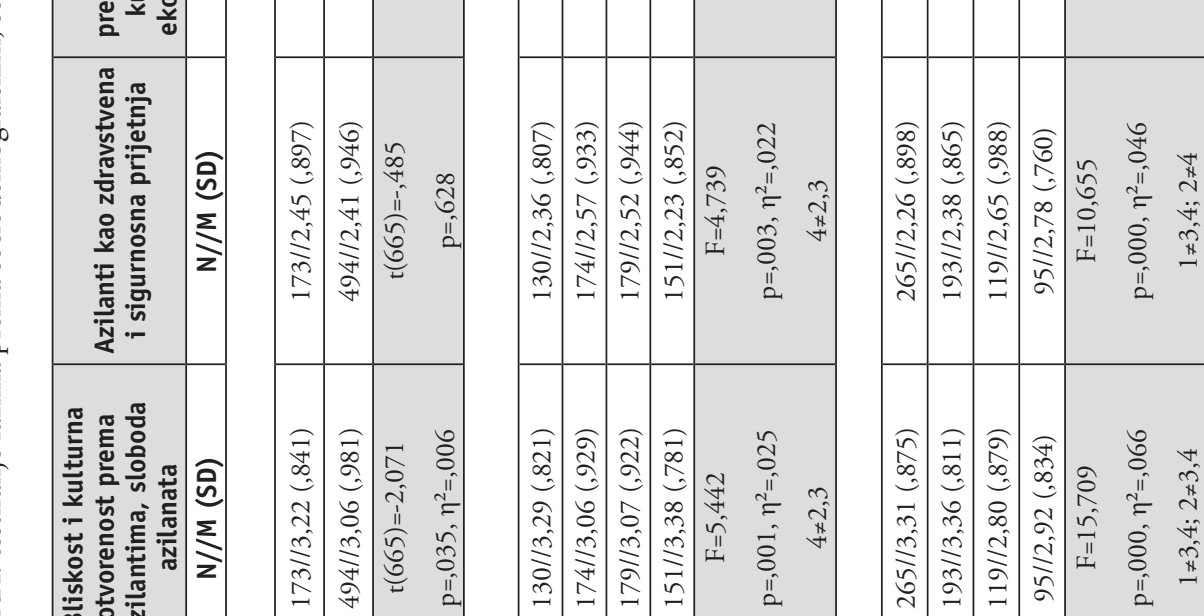

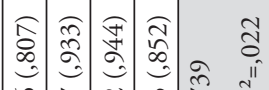

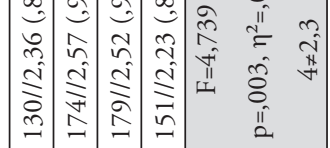

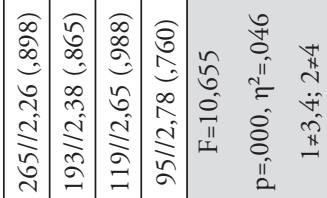

$\therefore \quad \ddot{\tilde{I}}$

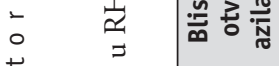

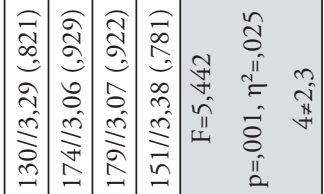

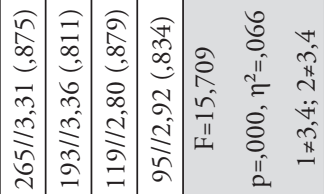

䇏量善
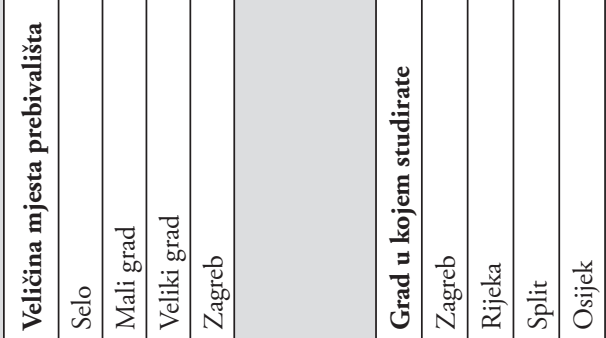


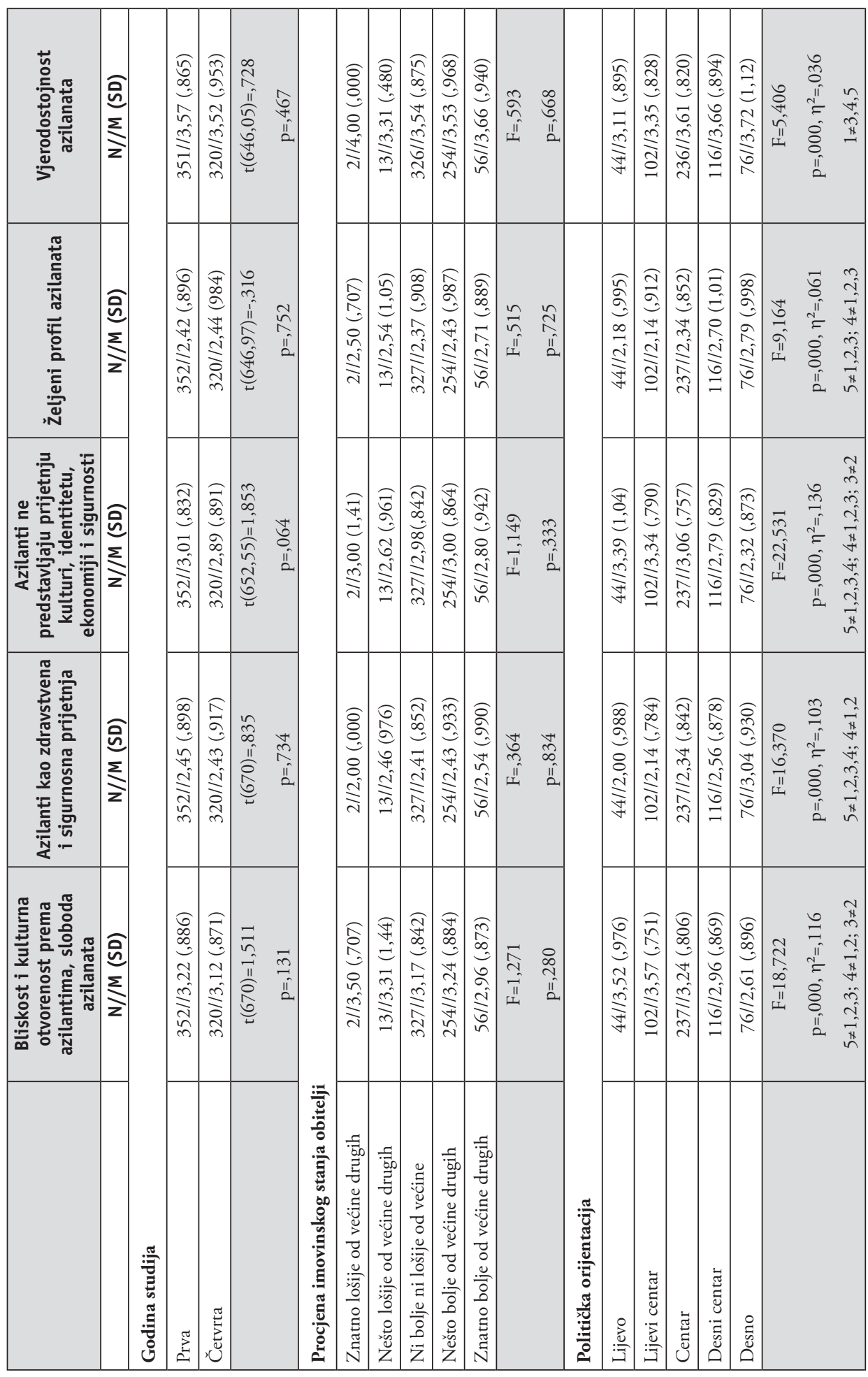




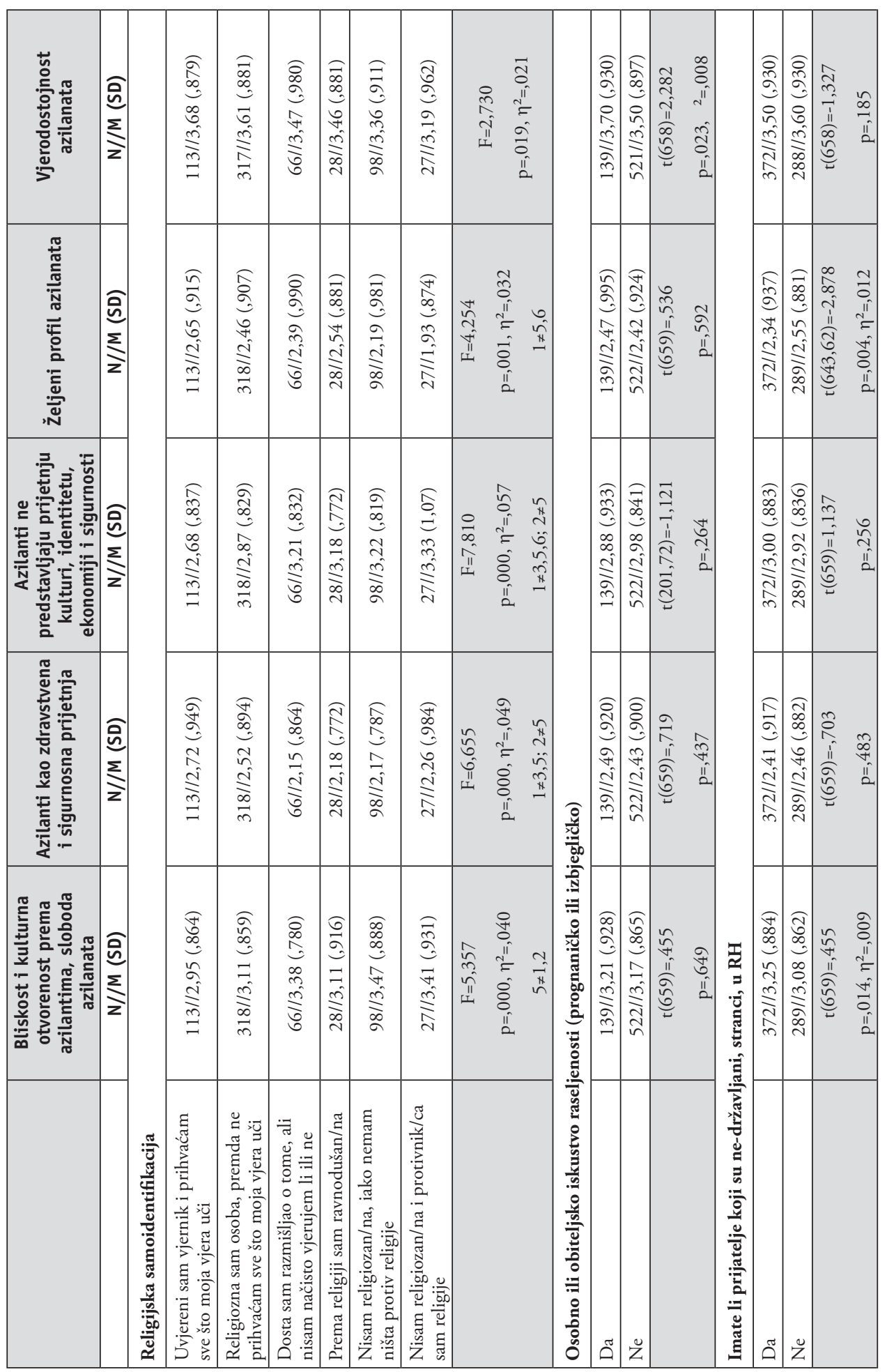




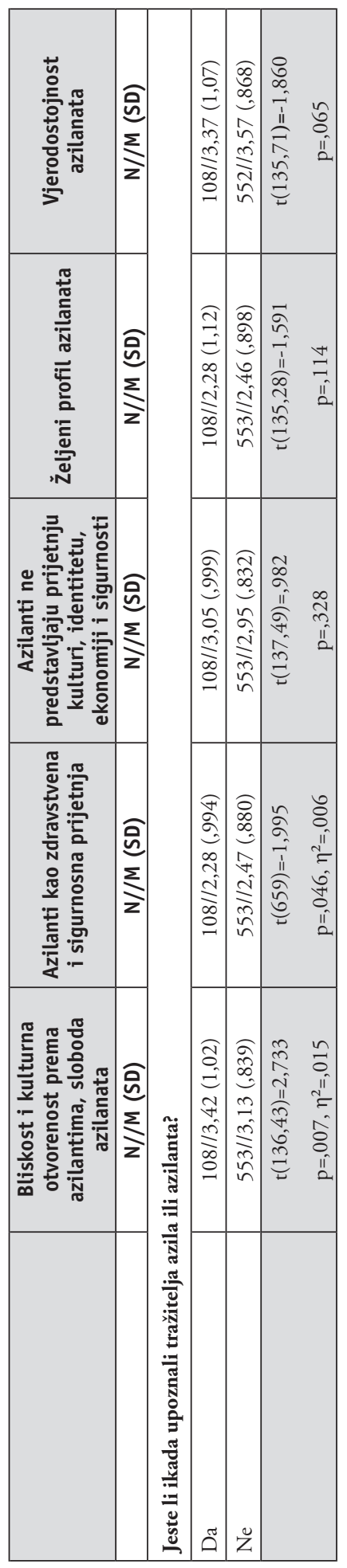




\title{
Enemy at the Gates? Or How Students of Law from Four Largest Croatian Cities Perceive Refugees and Migrants from the Middle East
}

\author{
Marko Mrakovčić \\ University of Rijeka, Faculty of Law, Croatia \\ e-mail:mmrakovcic@pravri.hr \\ Margareta Gregurović \\ Institute for Migration and Ethnic Studies, Zagreb, Croatia \\ e-mail: margareta.gregurovic@imin.hr
}

\begin{abstract}
In this paper the authors analyse the attitudes of law students towards migrants from the Middle East and refugees in the Republic of Croatia. Survey was conducted in 2019 at four Croatian faculties of law: in Zagreb, Rijeka, Split and Osijek (N=667). The conceptual framework was primarily based in conflict theories, i.e., group threat theory and integrated threat theory. The aim of the study was to analyse how students of law perceive migrants from the Middle East and refugees in Croatia, and whether they consider them to be a real or symbolic threat to Croatia and EU countries. The paper also examines differences in attitudes among students of different sociodemographic and sociocultural characteristics. The results showed that political orientation, degree of (non)religiosity and cities from which respondents come are significantly related to students' attitudes towards migrants and refugees. It has also been determined that there is a significant correlation between the attitudes towards refugees in the Republic of Croatia and the general attitudes of respondents towards migrants from the Middle East. The strongest, positive effect on these attitudes had the readiness for closeness and cultural openness towards refugees and lack of perception that refugees pose potential or real threat to society in which they are moving to.
\end{abstract}

Key words: migrants, refugees, threat perception, attitudes, students of law. 